\title{
14. COMPOSITION AND CONDITIONS OF GENESIS OF SEDIMENTARY ROCKS IN THE LOWER PART OF SITE 462, DEEP SEA DRILLING PROJECT LEG $61^{1}$
}

\author{
P. P. Timofeev, V. I. Koporulin, I. M. Varentsov, V. V. Eremeev, and D. Ya. Choporov, Geological Institute, \\ U.S.S.R. Academy of Sciences, Moscow, U.S.S.R.
}

\begin{abstract}
Cretaceous volcaniclastic rocks from the lower part of Deep Sea Drilling Project Hole 462 (Cores 14-80) were studied under the microscope. X-ray study of clay minerals and authigenic zeolites and amphiboles was also made. Altered hyalobasalts and palagonitized (or replaced by $\mathrm{Fe}-\mathrm{Mg}$-smectite) sideromelanic glass are predominant in the rock composition. Acid to basic plagioclases, basic volcanic glass, biotite, pyroxene, hornblende, and olivine were recognized in sediments. Accumulation of sediments took place in relatively deep-water environments, whereas transportation of volcaniclastic material was by turbidite flows. In the zone of doleritic sills, the volcaniclastic rocks were subjected to hydrothermal and contact-metasomatic alteration, resulting in formation of authigenic zeolites (analcime, wairakite [?], thomsonite) and monoclinic amphiboles (tremolite, actinolite).

Geochemical study of volcaniclastic sediments shows them to be products of transportation of tholeitic basalt material which interacted with sea water. An increase in content of $\mathrm{Fe}^{3+}, \mathrm{K}, \mathrm{Mn}$, and heavy metals $(\mathrm{Cu}, \mathrm{Ni}, \mathrm{Co}, \mathrm{V})$ is observed in this succession: tholeitic basalts, their hyaloclastites, smectitic clays. A similar tendency is observed in a transitional zone from the lower horizons of the sequence (Barremian) to the upper ones (Cenomanian).
\end{abstract}

\section{INTRODUCTION}

The lower part of the section of DSDP Site 462 (depth interval $546-1115 \mathrm{~m}$ ) is composed mostly of igneous rocks: basalts and diabases, including their extrusive varieties. They form bodies from a few meters to some tens of meters thick. Horizons of sedimentary rocks forming interbeds of a few centimeters to 30 meters have been recognized within igneous rocks. This paper is devoted to elucidation of the composition, conditions of accumulation, and secondary changes of such sedimentary rocks.

The studies were aimed at analysis of structural peculiarities of rocks, composition of rock-forming and accessory components, cement, and chemical composition. They were carried out through a complex of methods, including a microscopic examination of thin sections and immersion specimens, and X-ray structural analysis of the clay fraction and some other components.

With a view toward more-precise diagnosis of the components composing the rocks, they were separated in heavy liquids in a centrifuge. This enabled us to obtain a considerable enrichment of the fractions with zeolites and amphiboles. The isolation of accessory minerals was carried out in bromoform in separation flasks.

Characterization of the material composition is based upon study of 26 samples from Cores $14,22,32,40,41$, 42,43 , and 80 . They present different lithological varieties: claystones (Samples 14-1, 66-69 cm and 75-79 cm), volcaniclastic silty claystones (Sample 32-1, 105-107 $\mathrm{cm}$ ), volcaniclastic siltstones (Samples 22-2, 70-72 cm

\footnotetext{
${ }^{1}$ Initial Reports of the Deep Sea Drilling Project, Volume 61.
}

and $88-90 \mathrm{~cm} ; 23-1,0-2 \mathrm{~cm} ; 32-1,148-150 \mathrm{~cm}$; 40-1, $140-142 \mathrm{~cm} ; 41-7,144-146 \mathrm{~cm}$ ), volcaniclastic finegrained sandstones (Samples 23-1, 4-6 cm; 32-2, 69-71 $\mathrm{cm}$ and $71-73 \mathrm{~cm}$; 41-7, 109-111 cm; 43-1, 86-89 cm; $80-1,10-13 \mathrm{~cm}$ and $18-21 \mathrm{~cm}$ ), volcaniclastic mediumand coarse-grained sandstones (Samples 40-1, 148-150 $\mathrm{cm} ; 42-1,54-56 \mathrm{~cm}$ and $56-58 \mathrm{~cm} ; 42-2,93-95 \mathrm{~cm}$ and 95-97 cm; 43-1, 140-142 cm; 43-2, 81-83 cm and 138$140 \mathrm{~cm} ; 80-2,86-88 \mathrm{~cm}$ and $88-90 \mathrm{~cm}$ ).

Thin sections of each of the samples have been studied; accessory minerals have been distinguished and examined in Samples 14-1, 66-69 cm; 23-1, 0-2 cm; 32-1, $148-150 \mathrm{~cm}$; 42-1, 54-56 cm; 42-2, 93-95 cm; 43-1, $86-89 \mathrm{~cm}$; and $80-2,88-90 \mathrm{~cm}$. Bulk chemical and quantitative spectral analysis have been done for Samples $14-1,75-78 \mathrm{~cm} ; 22-2,70-72 \mathrm{~cm}$ and $88-90 \mathrm{~cm} ; 23-1,4-6$ $\mathrm{cm} ; 32-1,105-107 \mathrm{~cm} ; 32-2,69-71 \mathrm{~cm} ; 40-1,140-142$ $\mathrm{cm} ; 41-7,144-146 \mathrm{~cm} ; 42-1,56-58 \mathrm{~cm} ; 43-2,138-140$ $\mathrm{cm} ; 80-1,18-21 \mathrm{~cm}$; and $80-2,86-88 \mathrm{~cm}$.

The clay fraction $(<0.001 \mathrm{~mm})$ was singled out from Samples 14-1, 66-69 cm; 23-2, 0-2 cm; 32-2, 71-73 cm, $42-2$, 95-97 cm, 43-1, 140-143 cm, and 80-1, 10-13 cm and studied by X-ray structural methods. The size fraction 0.1 to $0.01 \mathrm{~mm}$ in Samples 42-2, 95-97 cm and 80-1, $10-13 \mathrm{~cm}$ was centrifuged in heavy liquid (density = $2.33 \mathrm{~g} / \mathrm{cm}^{3}$ ), and the zeolites distinguished in the light fraction were studied by X-ray diffraction. In Sample $41-7,109-111 \mathrm{~cm}$, the fraction 0.1 to $0.01 \mathrm{~mm}$ was centrifuged in heavy liquid with a density of $3.00 \mathrm{~g} / \mathrm{cm}^{3}$; the heavy fraction enriched with authigenic amphiboles was studied by X-ray diffraction.

\section{GENERAL LITHOLOGICAL CHARACTERISTIC OF ROCKS}

The volcaniclastic gritstones, sandstones, siltstones, and claystones from the lower part of the section in 
Hole 462A are greenish-gray, olive-green, or dark-green, varieties with a red-brownish tint being observed too. These usually contain a considerable admixture of clay material, are non-laminated, or have vague, less frequently distinct lamination: horizontal (continuous or discontinuous), oblique wave-like (flow-ripple marks), small oblique lamination with different inclination angles of laminae within each oblique series (Fig. 1). The lamination is due to changes in the granulometric composition.

These types of lamination are best pronounced in silty-clayey and fine-sand varieties of rocks. Mediumand coarse-grained sandstones are usually non-laminated (Fig. 2), or contain slide textures (Fig. 3). The latter are a series of irregular, obliquely inclined laminae differing in granulometric composition; this resembles oblique lamination. The inclination angles of laminae in each series vary from 10 to $15^{\circ}$ to 40 to $60^{\circ}$. In gritstones and conglomerates (breccias), a monotonous orientation of flattened pebbles is frequently seen. It bespeaks the existence of oblique, apparently very irregular lamination (Fig. 4).

Sandy-gravelly or gravelly-pebble rocks varieties in the section alternate with silty-clay rock. Gradual transitions of coarse-grained varieties into more fine-grained ones are frequently observed. Such a transition is observed most frequently upward in the section, reverse relationships being, however, observed as well. The rocks (with a few exceptions) are devoid of remains of life. An accumulation of strongly silicified radiolarians was observed in Sample 14-1, 66-69 cm; single radiolarians replaced by zeolite are present in Samples 40-1, $140-142 \mathrm{~cm} ; 40-1,148-150 \mathrm{~cm}$; and 41-7, 144-146.

Accumulations of pyritized plant remains were found in Core 40-1. Agglutinated foraminifers, fish bones, and radiolarians of Barremian age are present in a thin interbeds of Core $80-1$. These remains, as well as other data, enable us to date the age of the entire complex of igneous and sedimentary rocks in the interval from Cenomanian to Barremian.

\section{ROCK-FORMING AND ACCESSORY CLASTIC COMPONENTS}

Diffractograms of light and heavy fractions in various samples, and distribution of authigenic minerals are shown in Figures 5 through 8.

The study showed the presence of the following rockforming clastic components in rocks:

1) Slightly altered basaltic glass-sideromelane (Plate 1, Figs. 1, 2). It is red-brown, golden red-brown, greenish red-brown, optically isotropic; refraction indices vary from 1.612 to 1.620 . The particles contain negligible amounts of small $(<1 \mu \mathrm{m})$ unrefinable inclusions of red-brown or black ore mineral.

2) Palagonitized basaltic glass (Plate 1, Figs. 3, 4) of red-brownish-yellow, golden yellow, red-brownish-green, and olive-green color. It is semi-transparent, isotropic under crossed nicols, and contains small amounts of dotted or flocculent inclusions of Fe-hydroxides a few microns across. Refraction indices vary from 1.600 to 1.570. Such fragments frequently have a zonal structure

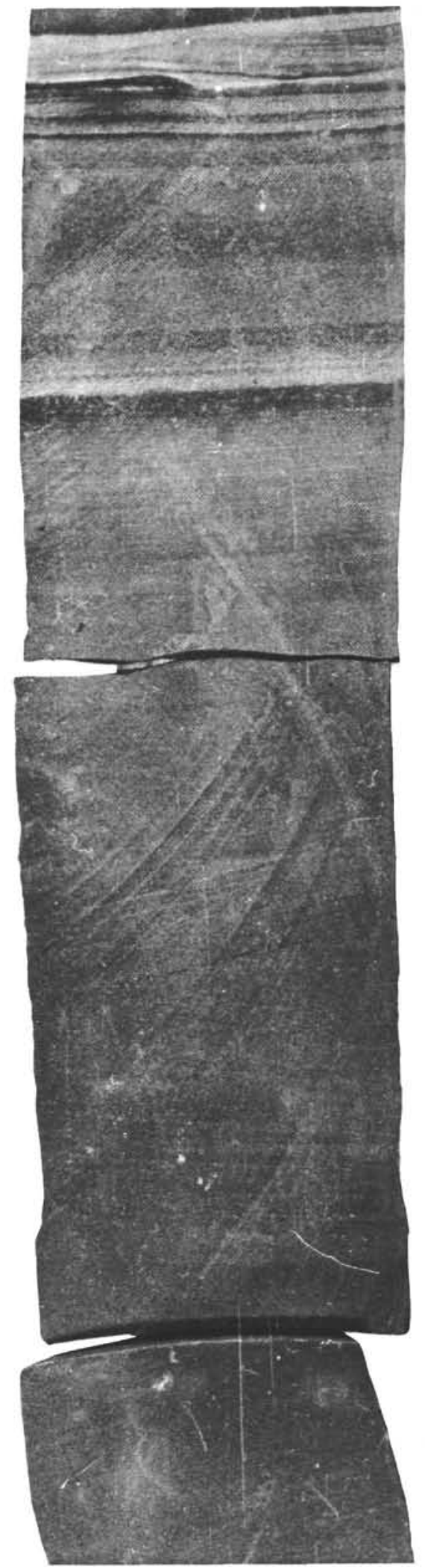

Figure 1. Sample $80-1,19-40 \mathrm{~cm}$. Volcaniclastic siltstone. Lamination (vague, small, oblique, flattened toward the base) in the lower part. Two oblique series are visible. The upper series is $3 \mathrm{~cm}$ thick, the lower one $5 \mathrm{~cm}$. Laminae in each series are inclined in opposite directions. In the upper part of the layer, the rock shows distinct horizontal lamination due to alternation of laminae of different colors and grain sizes. A thin interbed with cross-wave-like lamination (current ripples). 


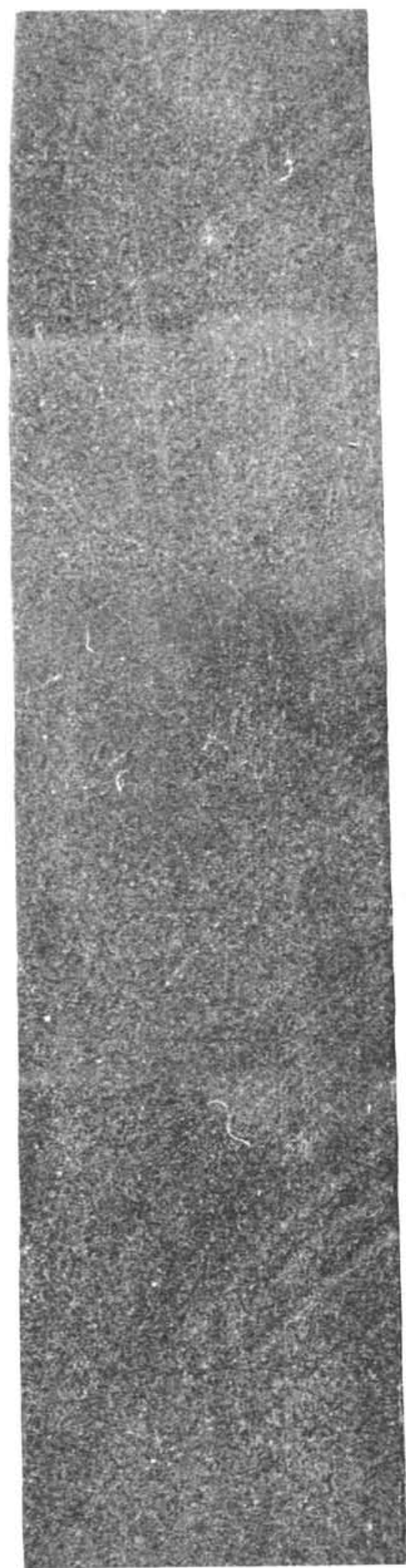

Figure 2. Sample $80-1,80-100 \mathrm{~cm}$. Volcaniclastic medium-grained sandstone. Irregular, nearly horizontal laminations, alternating in color and granulometric composition. The boundaries between them are vague and uneven.

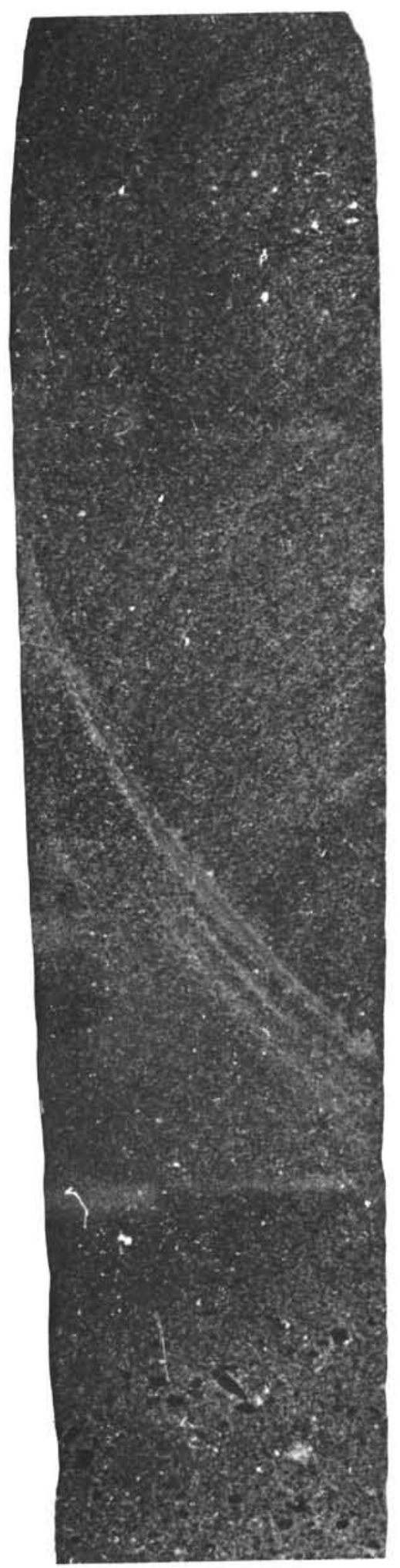

Figure 3. Sample $80-1,59-79 \mathrm{~cm}$. Volcaniclastic medium- and coarsegrained sandstone with an admixture of gravel-sized fragments and fine-grained gritstone in the lower part. Gradual transitions of different lithological varieties. Barely discernable slide texture with about $65^{\circ}$ inclination of layers. The laminae differ in grain size; thickness is not over 2 to $3 \mathrm{~mm}$. 


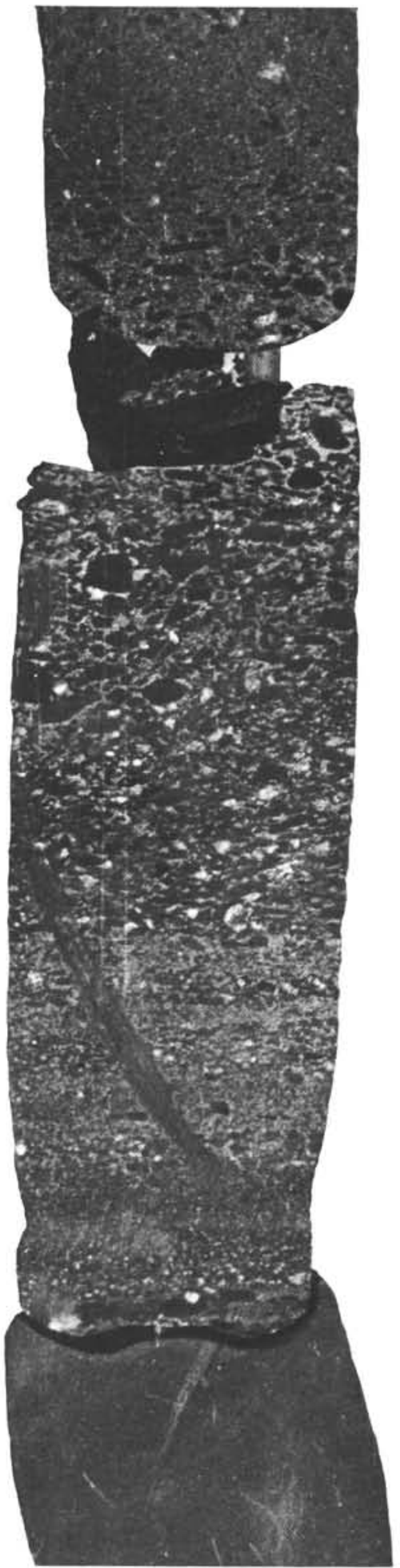

Figure 4. Sample $80-1,39-61 \mathrm{~cm}$. In the middle part is a bed of volcanomictic inequigranular gritstone, passing upward into volcanomictic fine-grained sandstone, and downward into volcanomictic coarse-grained sandstone. Gritstones in the lower part of the layer consist mostly of medium- and coarse-gravel-sized fragments $(>2.5 \mathrm{~mm})$; elongated fragments are frequently oriented in one direction here, emphasizing irregular lamination. The upper part abounds in sandy and fine-gravel-sized material; distinct horizontal lamination. The upper contact of the gritstone layer is distinct; the transition into the underlying rock is gradual. and consist of concentric bands 3 to $5 \mu \mathrm{m}$ wide, colored various tints of red-brownish-yellow or red-brownishgreen. Their boundaries are often accentuated by concentric fissures. It has been shown by a number of researchers that the process of palagonitization of volcanic glass is expressed in a higher content of water and an outflow of such components as $\mathrm{Na}, \mathrm{Ca}$, and $\mathrm{SiO}_{2}$ (Hay and Ijima, 1968; Stokes, 1971; Geptner, 1978). Subsequently, clay minerals are formed after palagonitic glass. The considered rocks contain the entire gamut of gradual transitions from varieties where palagonitization was slightly pronounced, to varieties that are on the verge of transformation into a clay aggregate. The former are yellowish-brown and yellow, and their refraction indices vary from 1.600 to 1.590 ; the latter are olive-green, and their refraction indices do not exceed 1.570 .

3) Basaltic (sideromelanic) glass replaced by clay material. Such fragments are green or olive-green. Their peripheral part is sometimes represented by a redbrown, opaque film up to $1-\mu \mathrm{m}$ wide; the central parts contain rounded vesicules up to $10 \mu \mathrm{m}$ in diameter, filled with green clay. Three varieties of this type of fragments are distinguished, differing in texture of clay materials: (i) Fragments of the first variety (Plate 1, Figs. 5, 6) are in habit similar to particles of glass with intense palagonitization. They are uniform in translucent light, and show under crossed nicols large-aggregate or cloudy extinction of gray, yellowish-gray, and orange-yellow interference color. Frequently, such material composes only the peripheral parts of fragments, whereas the central parts consist of isotropic palagonitized basaltic glass. (ii) Fragments of the second variety (Plate 2, Figs. 1, 2) have a thin aggregate texture and consist of slightly differentiated clay particles sized not over 2 to $3 \mu \mathrm{m}$. The latter show pleochroism in transmitted light, and under crossed nicols they show gray, white, or yellow interference color. The peripheral parts of such fragments are of incrustate structure, composed of small needles oriented perpendicular to the surface. The width of the rim is 5 to $6 \mu \mathrm{m}$. It forms practically all elongated and thin fragments, and in large and equant fragments a small outer part only. The central parts of the fragments are filled with oriented particles. Accumulations of red-brown or black ore minerals, relics of palagonitized glass or the above-described clay material of homogenous texture, are frequent here. (iii) Fragments of the third variety (Plate 2, Fig. 3) resemble those of the first one, but the clay particles are larger (up to 5-6 $\mu \mathrm{m}$ ), more distinctly differentiated, and frequently show a well-pronounced pleochroism and higher birefringence (orange interference colors).

Refraction indices of clay material composing the fragments of all three varieties showed considerable similarity: $\mathrm{Ng}_{1}=1.570 ; \mathrm{Np}_{1}=1.540 ; \mathrm{Ng}-\mathrm{Np}=0.030$.

4) Strongly altered hyalobasalts. Fragments of this type (Plate 2, Figs. 4-6) are red-brown or black, and opaque or semi-transparent. The color apparently depends on the form and content of iron: in red-brown varieties these are Fe-hydroxides, in black varieties magnetite or hematite. Semi-transparent varieties under 


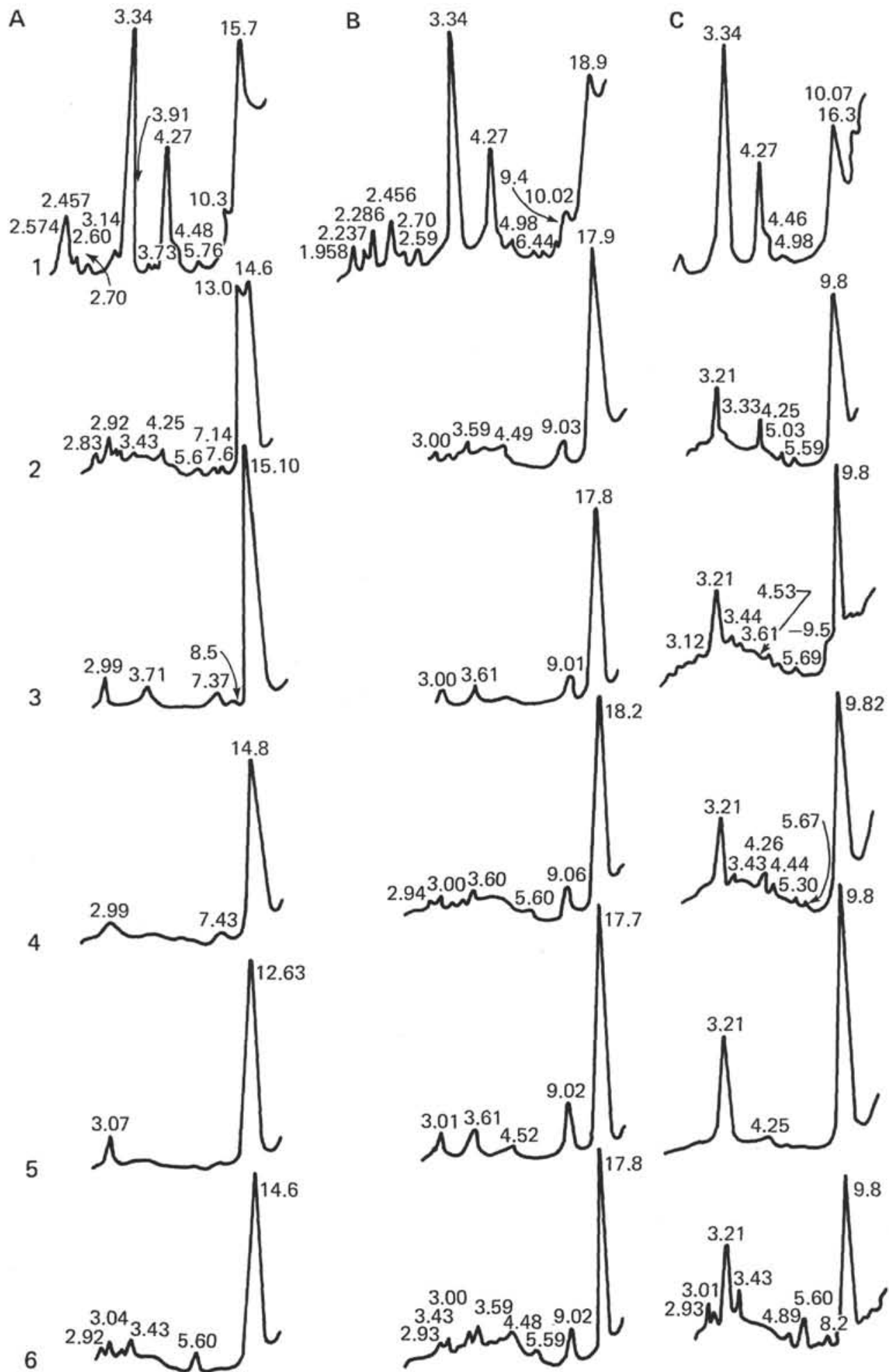

Figure 5. Diffractograms of the $<0.001-\mathrm{mm}$ fraction from Samples 1-14, 66-69 $\mathrm{cm} ; 2-23,0-2 \mathrm{~cm} ; 3-32$, 71-73 cm; 4-42, 95-97 cm; 5-13,140-143 cm; 6-80, 10-13 cm. A. Air-dry state. B. Saturated with glycerine. C. After heating at $550^{\circ} \mathrm{C}$. 


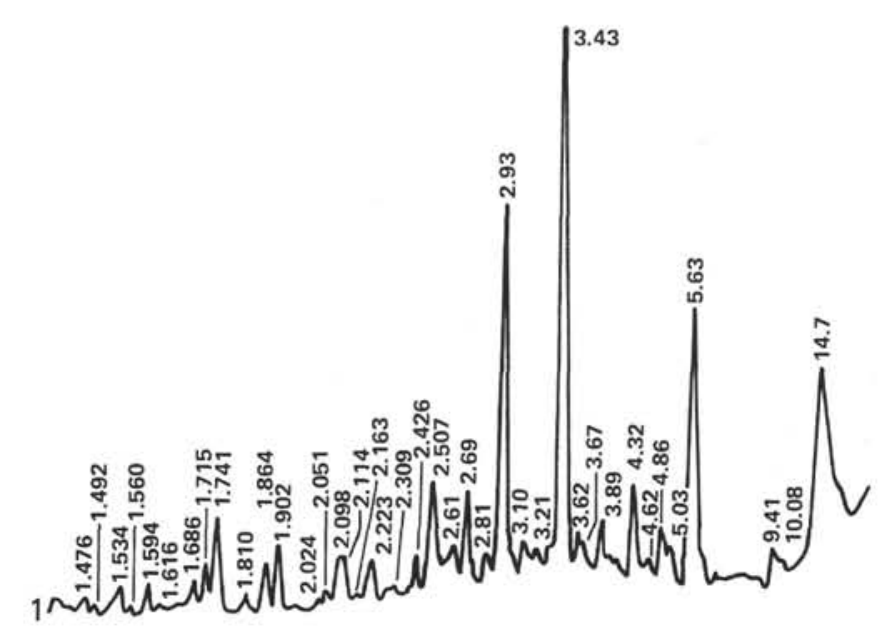

2 M

Figure 6. Diffractograms of the light part of the $0.1-0.01-\mathrm{mm}$ fraction separated in a liquid with density of $2.3 \mathrm{~g} / \mathrm{cm}^{3}$. Samples $1-42$, $95-97 \mathrm{~cm} ; 2-80,10-13 \mathrm{~cm}$.

crossed nicols show aggregate polarization. In many fragments of such type these are small rounded cavities (up to $10 \mu \mathrm{m}$ ) filled with clay material as well as plagioclase microlites (up to $3-4 \mu \mathrm{m}$ ). The clay material in the cavities is of incrustate texture, and a finely dispersed clay mass of green color is frequently formed after the material of the rest of the fragment. These are commonly the areas with minimal content of red-brown patches of Fe-hydroxides. Microlites of plagioclase are always heavily decomposed. Nevertheless, they are clearly distinguished within the red-brown mass enclosing them. We did not measure the plagioclase content, because of its altered condition.

5) Semi-crystalline basaltic glass of incrustate structure (Plate 3, Figs. 1, 2). Particles of this kind are redbrown or pale red-brown, and consist of elongated fibers or plates oriented perpendicular to the surface of fragments. Each of the particles has a direct extinction, and dark-gray, gray, or yellowish-gray interference colors. The whole grain shows cloudy or mosaic extinction. Frequently, fragments of such composition contain in the middle a "suture" line separating them into parts, each of them of incrustate structure. There may be observed rounded or prismatic fragments. The former are a radial-ray sphere with a vesicle in the center.

6) Unaltered or insignificantly altered glass of intermediate composition. It is colorless in transmitted light and isotropic under crossed nicols. The refraction indices vary from 1.500 to 1.520 . According to the data of Tröger (1952), volcanic glass with such refraction indices corresponds to intermediate (andesite-dacite) igneous rocks.

7) Plagioclases as fresh or heavily altered grains. Grains of fresh plagioclases are transparent (Plate 3, Fig. 3), colorless, with distinct cleavage cracks; under crossed nicols they frequently show twinning bands. Albite, andesite, labradorite, and bytownite were recognized among such well-preserved plagioclases by optical methods. Heavily altered plagioclases (Plate 3, Figs. 4-6) retain prismatic outlines of the original grain, although they are completely replaced by new minerals: zeolite, clay minerals frequently associated with patches of ore minerals, and sometimes authigenic amphiboles.

8) Green or reddish-brown biotite scales from 0.1 to $0.2 \mathrm{~mm}$ along the axis. Biotite is strongly hydrated and characterized by low birefringence (yellow and orangeyellow colors of interference) and weak pleochroism; cleavage cracks are hardly noticeable.

All these rock-forming clastic grains are usually of irregular shape. Plagioclases are present as short-prismatic or considerably elongated crystals. Particles of volcanic glass are equant, strongly elongated, distinctly polygonal. The latter characteristic is peculiar even to the glass particles replaced by clay material, despite susceptibility to mechanical destruction. On the contrary, an appreciably rounded shape is representative even of altered hyalobasalt particles. Such particles are

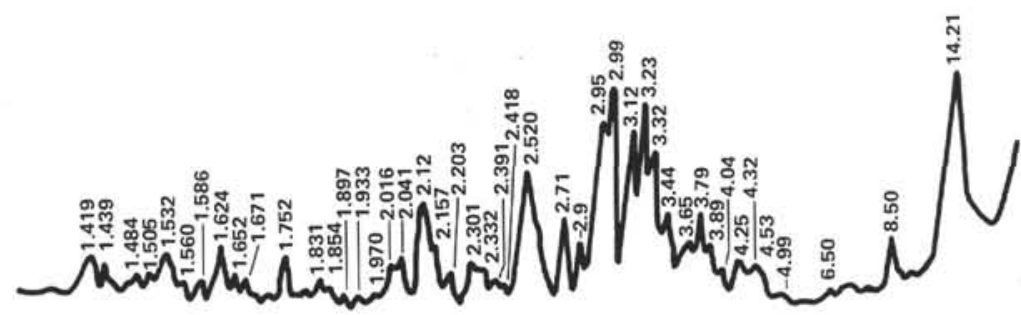

Figure 7. Diffractogram of the heavy fraction of the 0.1-0.01-mm fraction of Sample $41-7,109-111 \mathrm{~cm}$, separated in a liquid with a density of $3.00 \mathrm{~g} / \mathrm{cm}^{3}$. 


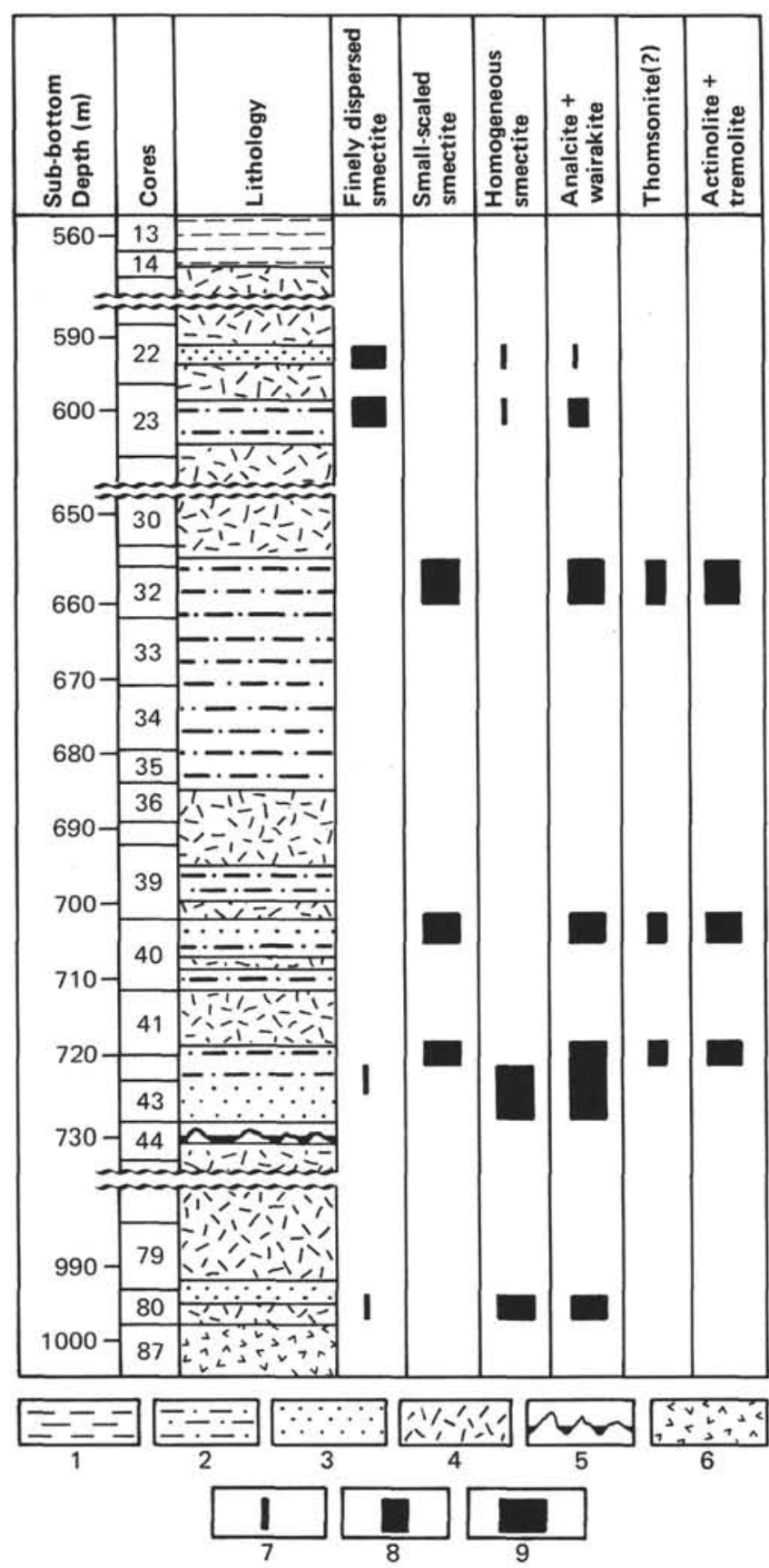

Figure 8. Distribution of authigenic minerals in volcaniclastic sedimentary rocks through the section. Lithology: 1, claystones, 2, siltstones, 3 , sandstones, 4 , diabases; 5 , extrusive rocks; 6 , basalts. Content of authigenic minerals: 7 , high; 8 , low; 9 , very low.

abundant in siltstones and fine-grained sandstones of Cores 22-2 and 23-1.

The contents of these components in rocks are very irregular. In siltstones and fine-grained sandstones of the upper horizons of the studied section (Samples 22-2, $70-72 \mathrm{~cm}$ and $88-90 \mathrm{~cm}, 23-1,0-2 \mathrm{~cm}$ and $4-6 \mathrm{~cm}$ ), glass particles prevail which are replaced by finely dispersed clay material, composing 45 to $65 \%$ of all clastic components. Fragments of altered hyalobasalts are of secondary significance $(25-45 \%)$. Contents of other vol- canic-glass types and plagioclases do not exceed a few percent.

In fine- to coarse-grained sandstones of the middle and lower horizons (Samples 42-1, 54-56 $\mathrm{cm}$ and 56-58 $\mathrm{cm} ; 42-2,95-97 \mathrm{~cm} ; 43-1,86-88 \mathrm{~cm}$ and $140-142 \mathrm{~cm}$; $43-2,138-140 \mathrm{~cm} ; 80-1,10-13 \mathrm{~cm}$ and $18-21 \mathrm{~cm} ; 80-2$, $86-88 \mathrm{~cm}$ and $88-90 \mathrm{~cm})$, among clastic components the altered hyalobasalts, composing 45 to $65 \%$, are of primary importance. Palagonitized glass and the glass replaced by coarse-aggregate clay material account for 10 to $15 \%$ (each variety). Slightly altered basaltic glass accounts for 5 to $10 \%$, and their components not over 2 to $3 \%$.

Volcaniclastic siltstones, claystones, and sandstones of the middle horizons of the section (samples from $32-1,32-2,40-1,41-2,41-7)$ were subjected to intense secondary changes, and it proved impossible to evaluate the contents of separate components in them.

Olivine, augite, leucoxene, magnetite, garnet, and pyrite were recognized by optical methods among accessory minerals.

Augite is irregular or short-prismatic, fresh or appreciably altered. Crystals of fresh augite show wellpronounced cleavage; they are of greenish-red-brown or pale-lilac color. Varieties of lilac color appear to belong to titaniferous augite. They are present in Samples 42-1, 54-56 cm; 42-2, 93-95 cm; and 43-1, 86-89 cm. In the rest of the samples they were not observed. Secondary changes of augite are expressed in uralitization, chloritization, and mica replacement.

Olivine is present as idiomorphic crystals replaced to various degrees by iddingsite, calcite, and hydrogoethite.

Ilmenite is present as small, elongated rhombohedrons or their fragments, replaced by leucoxene to various degrees.

Leucoxene occurs as earthy aggregates, and less frequently as elongated grains of rhombohedral shape. This mineral is likely related to replacement of ilmenite.

Magnetite is present as platy crystals and underdeveloped skeletal aggregates.

Garnet was recognized sporadically in Sample 42-1, $54-56 \mathrm{~cm}$ as colorless, angularly rounded grains with traces of dissolution on the surface.

Pyrite occurs as crystals of cubic habit, or their irregular aggregations. Some of them are replaced by hydrogoethite.

The contents of all these minerals in the heavy fraction is shown in Table 1.

\section{GEOCHEMISTRY OF VOLCANICLASTIC DEPOSITS}

\section{The Problem Stated}

The Cenomanian-Barremian complex of volcaniclastic sediments recovered from Hole $462 \mathrm{can}$ be regarded on the whole as redeposited products of tholeiitic oceanic volcanism in the axial zones (Bailey and NoeNygaard, 1976; Campsie et al., 1973; Hekinian and Thompson, 1976; Thompson et al., 1972). 
Table 1. Accessory minerals of volcaniclastic rocks from the lower part of Hole 462A.

\begin{tabular}{|c|c|c|c|c|c|c|c|}
\hline \multirow{2}{*}{$\begin{array}{c}\text { Sample } \\
\text { (interval in } \mathrm{cm} \text { ) }\end{array}$} & \multirow{2}{*}{$\begin{array}{c}\text { Heavy } \\
\text { Fraction } \\
(0.1-0.01 \mathrm{~mm}) \\
(\%)\end{array}$} & \multicolumn{6}{|c|}{ Mineral Composition of Heavy Fraction $(\%)$} \\
\hline & & Augite & Olivine & Leucoxene & Ilmenite & Magnetite & Pyrite \\
\hline $462 A-14-1,66-69$ & 0.01 & - & - & - & - & - & 100 \\
\hline $23-1,0-2$ & 0.02 & 20 & - & - & - & - & 80 \\
\hline $32-1,148-150$ & 0.01 & 5 & - & - & - & - & 95 \\
\hline $40-1,148-150$ & 0.01 & - & - & - & - & - & 100 \\
\hline $42-1,54-56$ & 0.01 & 60 & 5 & 20 & 10 & - & 5 \\
\hline $42-2,93-95$ & 0.05 & 70 & 5 & - & 15 & 5 & 5 \\
\hline $43-1,86-89$ & 0.04 & 70 & - & 10 & 15 & 3 & 2 \\
\hline $80-2,88-90$ & 0.01 & 60 & - & 25 & 10 & - & 5 \\
\hline
\end{tabular}

Lithological and mineralogical features of these deposits are given above. It should be mentioned that the main features of authigenic transformations of initial materials of tholeiitic composition were determined by low-temperature interactions with sea water on the one hand, and high-temperature, contact-hydrothermal processes on the other. The scale of these processes, the influence of their chemistry on formation of the authigenic sedimentary material, and the composition of the sea water have at least wide regional-and in some periods global-significance (Seyfreid and Bishoff, 1977; Varentsov, 1971).

The objective of the geochemical investigations was an understanding of the chemical nature of authigenic transformations in the sediments concerned and, if possible, establishment of a quantitative correlation among these processes.

\section{METHODS}

Geochemical study of the deposits was carried out on the basis of lithological-mineralogical data. Determination of chemical components of the sediments was made in the laboratory of the Geological Institute of the U.S.S.R. Academy of Sciences: main components by the method of bulk analysis, heavy metals by optical emission spectroscopy (Zolotarev and Choporov, 1978). The analytical data were evaluated by EC-1022 in the laboratory of mathematical methods (by D. A. Kazimirov and P. K. Ryabushkin) by factor analysis (Davis, 1973; Harman, 1967).

\section{Paragenetic Associations of Components and Their Distribution}

The succession of authigenic transformations of the initial fragmental material of tholeiitic basalts reflected in the mineral and chemical composition of the Cretaceous sediments is: from volcaniclastic coarse sandstones to $\mathrm{Fe}-\mathrm{Mg}$ smectitic, illitized and zeolitized clays. The influence of contact-metasomatic and hydrothermal alterations considerably complicated a general trend of authigenic transformations (Tables 2 and 3 ). It is particularly clear that these processes result in an isolation of geochemical groups or paragenetic associations of components connected by relatively strong correlative bonds.

Establishment of associations are made on the basis of grouping of components with considerable factor loads $(>0.3)$ of the same sign. Each association is regarded on the basis of mineral composition and processes possible under these conditions. With the aim of more clear understanding of correlations between association components, each chemical component was defined by a value of factor load, given in brackets, for the factor it most closely connected with. Typical loads on other factors for each association concerned are close to 0 . Transformation of data by the method of rotation was done to obtain better-expressed values of factor loads (Davis, 1973).

Association IA (Tables 4 and 5): Manganese Oxide and Free Silica: $\mathrm{SiO}_{2}(0.88), \mathrm{MnO}(0.88), \mathrm{Ni}(0.74)$, Co (0.61), Pb (0.95)

The association concerned is abundant mainly in finely dispersed Cenomanian clays (Sample 14-1 75-78 $\mathrm{cm}$ ) composed of $\mathrm{Fe}-\mathrm{Mg}$ smectite with considerable admixture of Mn, Fe hydroxyls, and illite (Table 2). The phase type of the association (Mn hydroxide enriched by $\mathrm{Ni}, \mathrm{Co}, \mathrm{Pb}$ and free, unbound $\mathrm{SiO}_{2}$ ) is an indication that these sediments formed from sea water which was considerably enriched by hydrothermal components.

$$
\begin{aligned}
& \text { Association IB (Tables } 4 \text { and 5): Altered Material } \\
& \text { of Tholeiitic Basalts: } \mathrm{TiO}_{2}(-0.94), \mathrm{Al}_{2} \mathrm{O}_{3}(-0.94) \text {, } \\
& \mathrm{FeO}(-0.71), \mathrm{MgO}(-0.94), \mathrm{Na}_{2} \mathrm{O}(-0.55), \\
& \mathrm{Cr}(-0.86), \mathrm{V}(-0.32), \mathrm{Ca}(-0.42)
\end{aligned}
$$

This association is predominant in the sediments concerned (dispersion $44.39 \%$ ) and is represented by aluminosilicate material of tholeiitic basalts at different stages of disintegration.

Association IIA (Tables 4 and 5): Plagioclases, Basis of Corresponding Composition, Zeolites: $\mathrm{Al}_{2} \mathrm{O}_{3}(0.31), \mathrm{CaO}(0.81), \mathrm{Na}_{2} \mathrm{O}(0.69), \mathrm{H}_{2} \mathrm{O}^{+}(0.78)$, $\mathrm{Ni}(0.34), \mathrm{V}(0.47), \mathrm{Co}(0.55), \mathrm{Ca}(0.70)$

This association occupies mainly the lower part of the sequence (Upper Aptian(?) to Hauterivian), with predominantly volcaniclastic, relatively weakly altered deposits.

\section{Association IIB (Tables 4 and 5): Hydromica Components, K-containing Smectites: $\mathrm{SiO}_{2}(-0.45)$, $\mathrm{K}_{2} \mathrm{O}$ (-0.90), $\mathrm{H}_{2} \mathrm{O}^{-}(-0.38)$}

This association is abundant in the Upper Aptian(?)Cenomanian sediments considerably enriched in authigenic smectite, and possibly by illite (Tables 2,4 ), formed as a result of low-temperature interaction with 
Table 2. Chemical composition of Cretaceous sedimentary rocks, Hole 462A.

\begin{tabular}{|c|c|c|c|c|c|c|c|c|c|c|c|c|c|c|c|c|c|c|c|c|c|c|c|c|c|c|c|}
\hline $\begin{array}{l}\text { Sample } \\
\text { No. }\end{array}$ & $\begin{array}{c}\text { Sample } \\
\text { Designation }\end{array}$ & $\mathrm{SiO}_{2}$ & $\mathrm{TiO}_{2}$ & $\mathrm{Al}_{2} \mathrm{O}_{3}$ & $\mathrm{Fe}_{2} \mathrm{O}_{3}$ & $\mathrm{FeO}$ & $\mathrm{MnO}$ & $\mathrm{CaO}$ & $\mathrm{MgO}$ & $\mathrm{Na}_{2} \mathrm{O}$ & $\mathrm{K}_{2} \mathrm{O}$ & $\mathrm{H}_{2} \mathrm{O}$ & L.o.i. & $\mathrm{H}_{2} \mathrm{O}$ & $\mathrm{CO}_{2}$ & c & $\mathrm{P}_{2} \mathrm{O}_{5}$ & Total & $\mathrm{Cr}$ & $\mathrm{Ni}$ & $\mathrm{v}$ & cu & Co & $\mathrm{Pb}$ & $\mathrm{Ga}$ & Ge & Mo \\
\hline 1 & $14-1,75-78 \mathrm{~cm}$ & 69.77 & 0.47 & 4.64 & 7.87 & 0.81 & 0.87 & 1.28 & 2.95 & 1.24 & 1.49 & 4.36 & - & 4.30 & 0 & 0 & 0.01 & 100.08 & 0.0016 & 0.0076 & 0.0165 & 0.0130 & 0.0047 & 0.0014 & $<0.0010$ & $<0.00015$ & 0.000 \\
\hline 2 & 2028 & 47.24 & 1.51 & 11.38 & 6.38 & 7 & 0.13 & 1.48 & 8.49 & 2.48 & 6.13 & & - & 5.63 & 0 & 0 & 0.01 & 100.44 & 0.0115 & 0.0036 & 0.0180 & 0.0095 & 0.0020 & $<0.0010$ & 0.0011 & & $\begin{array}{r}<0.00015 \\
<00015\end{array}$ \\
\hline${ }_{4}^{3}$ & $22-2,88-9$ & $\begin{array}{l}46.08 \\
45.40\end{array}$ & $\begin{array}{l}1.29 \\
1.43\end{array}$ & 10.74 & $\begin{array}{l}7.16 \\
6.50\end{array}$ & 4.72 & 0.06 & 2.17 & $\begin{array}{r}9.67 \\
910.43\end{array}$ & 2.52 & 4.64 & 5.67 & $\overline{-}$ & $\begin{array}{l}7.11 \\
5.69\end{array}$ & 0 & $\stackrel{0}{0}$ & 0.01 & 99.84 & 0.0135 & 0.0048 & 0.0250 & 0.0085 & 0.0027 & $<0.0010$ & 0.0014 & $=0.00015$ & $\begin{array}{l}0.00015 \\
0.00015\end{array}$ \\
\hline $\begin{array}{l}4 \\
5\end{array}$ & $\begin{array}{l}23-1,4-6 \\
32-105-107\end{array}$ & $\begin{array}{l}45.40 \\
41.54\end{array}$ & $\begin{array}{l}1.43 \\
1.25\end{array}$ & 12.10 & $\begin{array}{l}6.50 \\
9.85\end{array}$ & 5.32 & $\begin{array}{l}0.14 \\
0.22\end{array}$ & $\begin{array}{l}1.60 \\
3.52\end{array}$ & $\begin{array}{l}10.43 \\
8.56\end{array}$ & $\begin{array}{l}3.11 \\
5.55\end{array}$ & $\begin{array}{l}3.51 \\
0.25\end{array}$ & $\begin{array}{l}5.08 \\
5.26\end{array}$ & $\overline{-}$ & $\begin{array}{r}5.69 \\
4.32\end{array}$ & $\begin{array}{l}0 \\
0\end{array}$ & ${ }_{0}^{0}$ & 0.01 & $\begin{array}{l}100.32 \\
99.62\end{array}$ & $\begin{array}{l}0.0120 \\
0.0099\end{array}$ & $\begin{array}{l}0.0043 \\
0.050\end{array}$ & $\begin{array}{l}0.0185 \\
0.025\end{array}$ & $\begin{array}{l}0.0090 \\
0.0150\end{array}$ & $\begin{array}{l}0.0023 \\
0.0046\end{array}$ & $\begin{array}{l}<0.0010 \\
<0.0010\end{array}$ & $\begin{array}{l}0.0013 \\
0.0020\end{array}$ & $<0.00015$ & $\begin{array}{l}<0.00015 \\
<0.00015\end{array}$ \\
\hline 6 & $\begin{array}{l}32-1,105-107 \\
32-2,69-71\end{array}$ & $\begin{array}{l}41.54 \\
43.54\end{array}$ & 1.34 & $\begin{array}{l}11.56 \\
10.96\end{array}$ & $\begin{array}{l}9.85 \\
3.62\end{array}$ & $\begin{array}{l}7.971 \\
9.94\end{array}$ & $\begin{array}{l}0.22 \\
0.21\end{array}$ & $\begin{array}{l}3.32 \\
5.43\end{array}$ & $\begin{array}{l}8.86 \\
9.12\end{array}$ & $\begin{array}{l}5.53 \\
5.75\end{array}$ & 0.25 & $\begin{array}{l}5.26 \\
5.50\end{array}$ & $\overline{-}$ & $\begin{array}{l}4.32 \\
4.66\end{array}$ & $\begin{array}{l}0 \\
0\end{array}$ & $\begin{array}{l}0 \\
0\end{array}$ & $\begin{array}{l}0.01 \\
0.01\end{array}$ & $\begin{array}{r}99.62 \\
100.08\end{array}$ & $\begin{array}{l}0.0099 \\
0.0100\end{array}$ & $\begin{array}{l}0.0050 \\
0.056\end{array}$ & $\begin{array}{l}0.0225 \\
0.0250\end{array}$ & $\begin{array}{l}0.01150 \\
0.0500\end{array}$ & $\begin{array}{l}0.0046 \\
0.0043\end{array}$ & $\begin{array}{l}<0.0010 \\
<0.0010\end{array}$ & $\begin{array}{l}0.0020 \\
0.0014\end{array}$ & $<0.00015$ & $\begin{array}{l}0.00015 \\
0.00015\end{array}$ \\
\hline 7 & $\begin{array}{l}32-2,69-71 \\
41-7,144-146\end{array}$ & 54 & 0.87 & $\begin{array}{l}11.90 \\
11.02\end{array}$ & $\begin{array}{l}3.62 \\
7.14\end{array}$ & 9.94 & & $\begin{array}{l}3.43 \\
4.99\end{array}$ & $\begin{array}{l}9.53 \\
9.53\end{array}$ & $\begin{array}{l}3.15 \\
5.15\end{array}$ & $\overline{0.74}$ & $\begin{array}{l}5.30 \\
5.03\end{array}$ & $\overline{-}$ & $\begin{array}{l}4.66 \\
3.18\end{array}$ & $\begin{array}{l}0 \\
0\end{array}$ & $\begin{array}{l}0 \\
0\end{array}$ & $\begin{array}{l}0.01 \\
0.01\end{array}$ & $\begin{array}{l}100.08 \\
100.12\end{array}$ & & $\begin{array}{l}0.00066 \\
0.0063\end{array}$ & $\begin{array}{l}0.0230 \\
0.0160\end{array}$ & $\begin{array}{l}0.00165 \\
0.05\end{array}$ & $\begin{array}{l}0.0025 \\
0.0025\end{array}$ & $\begin{array}{l}<0.0010 \\
<0.0010\end{array}$ & & & $\begin{array}{l}0.00015 \\
0.00015\end{array}$ \\
\hline 8 & $42-1,56-$ & 45.62 & 1.26 & 11.28 & 10.53 & 1.00 & 0.19 & 4.96 & 8.87 & 56 & 0.47 & & - & 5.32 & 0 & 0 & 0.01 & 99.90 & 0.0063 & 0.0043 & 0.0250 & 0.0110 & 0.0033 & $<0.0010$ & 0.0012 & $<0.00015$ & 0.0 \\
\hline 3 & $43-2,138-140$ & & 1.02 & 11.36 & & & & 5.53 & 9.90 & 52 & 0. & 4.92 & - & 4.36 & 0 & 0 & 0.01 & 100.51 & 0.0187 & 0.0055 & 0.0165 & 0.0078 & 0.0030 & $<0.0010$ & 0.0013 & $<0.00015$ & 0.00 \\
\hline 10 & $80-1,18$ & 48.24 & 1.19 & 10. & 6.51 & 5.83 & 0.17 & 5.65 & & 4.40 & 1.63 & 4.44 & - & 3.98 & 0 & 0 & 0.01 & 100.50 & 0.0100 & 0.0047 & 0.0235 & 0.0110 & 0.0028 & $<0.0010$ & 0.0014 & & $\begin{array}{l}<0.0001 \\
<0.0001\end{array}$ \\
\hline 11 & $80-2,86-$ & & 0.85 & 11.80 & 7.16 & 5.19 & 0.18 & 7.98 & 7.65 & 3.84 & 0.05 & 5.58 & $-\bar{x}$ & 5.13 & 0 & 0 & 0.01 & 99.84 & 0.0150 & 0.0063 & 0.0260 & 0.0110 & 0.0035 & $<0.0010$ & 0.0015 & $<0.00015$ & $<0.00015$ \\
\hline 12 & $\mathrm{U}_{\mathrm{U}}^{49}$ & $\begin{array}{l}488.80 \\
48.82\end{array}$ & $\begin{array}{l}0.93 \\
0.91\end{array}$ & $\begin{array}{l}14.07 \\
14.04\end{array}$ & $1204^{b}$ & $10.85^{\mathrm{a}}$ & $\bar{z}$ & $\begin{array}{l}12.59 \\
12.67\end{array}$ & 7.70 & 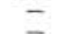 & $\begin{array}{l}0.049 \\
0.03\end{array}$ & 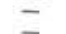 & 0.14 & z & $\bar{z}$ & $\bar{z}$ & $\overline{-}$ & $\bar{z}$ & $\bar{z}$ & $\bar{z}$ & 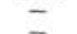 & $\bar{z}$ & - & - & - & - & $\bar{z}$ \\
\hline 14 & Unit 24 & $\begin{array}{l}48.82 \\
48.93\end{array}$ & $\begin{array}{l}0.91 \\
0.95\end{array}$ & $\begin{array}{l}14.04 \\
13.83\end{array}$ & & $\bar{z}$ & $=$ & & & $\bar{z}$ & & $\bar{z}$ & & $\Xi$ & $\overline{-}$ & $\bar{z}$ & $z$ & $\bar{z}$ & $\overline{-}$ & $\overline{-}$ & $\bar{z}$ & $\overline{-}$ & $\overline{-}$ & $\overline{-}$ & - & - & $\bar{z}$ \\
\hline is & Unit 29 & 47.70 & 1.01 & 13.67 & 12.20 & - & - & 12.43 & & - & 0 . & - & 0. & - & - & - & - & - & - & - & - & - & - & - & - & - & - \\
\hline 16 & Unit 3 & 49.69 & 1.03 & 13.97 & 12.21 & - & - & 12.62 & 7.55 & - & 0.03 & - & 0.50 & - & - & - & - & - & - & - & - & - & - & - & - & - & - \\
\hline 17 & $\begin{array}{l}\text { Mid-Pacific Ridge } \\
\text { (avg.) }\end{array}$ & 49.22 & 1.39 & 15.81 & 2.21 & 7.19 & 0.16 & 11.14 & 8.53 & 2.71 & 0.15 & - & - & - & - & - & 0.15 & 98.66 & 0.0280 & 0.0100 & 0.0289 & 0.0070 & 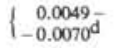 & - & 0.0018 & - & - \\
\hline 18 & $\begin{array}{l}\text { Tholeitite, Galapagos } \\
\text { Islands Rift Valleye }\end{array}$ & 48.36 & 2.65 & 14.53 & 3.52 & 8.79 & 0.18 & 11.45 & 6.63 & 2.69 & 0.36 & 0.61 & - & 0.17 & - & - & 0.25 & 99.99 & - & - & - & - & - & - & - & - & - \\
\hline 19 & Ocean tholeitites ${ }^{f}$ & - & - & - & - & - & - & - & - & - & - & - & - & - & - & - & - & - & $\left\{\begin{array}{l}0.0180 \\
0.0500\end{array}\right.$ & $\begin{array}{l}0.0095 \\
0.0215\end{array}$ & $\begin{array}{l}0.0270 \\
0.0375\end{array}$ & $\begin{array}{l}0.0058 \\
0.0072\end{array}$ & $\begin{array}{l}0.0039 \\
0.0045\end{array}$ & $\begin{array}{r}<0.0002 \\
0.0003\end{array}$ & $\begin{array}{l}0.0012 \\
0.0018\end{array}$ & - & - \\
\hline
\end{tabular}

a $\mathrm{FeO}=$ total ferrous oxide.

${ }^{2} \mathrm{Fe}_{2} \mathrm{O}_{3}=$ total ferric oxide.

d Bailey and Noe-Nygaard (1976); Hekinian and Thompson (1976).

e Campsie et al. (1973),
Thompson et al., (1972).

Table 3. Heavy-metal contents and geochemical characteristics of Nauru Basin volcaniclastic sedimentary rocks.

\begin{tabular}{|c|c|c|c|c|c|c|c|c|c|c|c|c|c|c|c|c|c|c|c|c|c|c|c|c|}
\hline \multirow{3}{*}{$\begin{array}{c}\text { Sample } \\
\text { No. }\end{array}$} & \multirow{3}{*}{$\begin{array}{c}\text { Sample } \\
\text { Designation }\end{array}$} & \multirow[b]{3}{*}{ Lithology } & \multirow[b]{3}{*}{$\mathrm{Ti}$} & \multirow[b]{3}{*}{ Al } & \multirow[b]{3}{*}{$\mathrm{Fe}^{3+}$} & \multirow[b]{3}{*}{$\mathrm{Fe}^{2+}$} & \multirow[b]{3}{*}{$\mathrm{Fe}_{\mathrm{tot}}$} & \multirow{3}{*}{$\frac{\mathrm{Fe}^{3+}}{\mathrm{Fe}_{\mathrm{tot}}}$} & \multirow[b]{3}{*}{$\mathrm{Mn}$} & \multirow{3}{*}{$\frac{\mathrm{Mn}}{\mathrm{Ti}_{\mathrm{i}}}$} & \multirow[b]{3}{*}{$\mathrm{Mg}$} & \multirow{3}{*}{$\frac{\mathrm{Mg}_{\mathrm{g}}}{\mathrm{Ti}}$} & \multirow[b]{3}{*}{$\mathrm{K}$} & \multirow{3}{*}{$\frac{K}{T i}$} & \multirow[b]{3}{*}{$\mathrm{EH}_{2} \mathrm{O}$} & \multicolumn{8}{|c|}{ Values $\times 10^{4}$} & \multirow{3}{*}{$\begin{array}{l}\text { Symbol in } \\
\text { Figures } 9,10\end{array}$} \\
\hline & & & & & & & & & & & & & & & & Al & $\mathrm{Fe}$ & $\underline{\mathrm{Cr}}$ & $\underline{\mathrm{Ni}}$ & $\underline{v}$ & $\underline{a_{u}}$ & Co & Ga & \\
\hline & & & & & & & & & & & & & & & & $\mathrm{Ti}$ & $\mathrm{Ti}$ & $\mathrm{Ti}$ & $\mathrm{Ti}$ & $\pi$ & $\mathrm{Ti}$ & $\mathrm{Ti}$ & $\mathrm{Ti}$ & \\
\hline 1 & $14-1,75-78 \mathrm{~cm}$ & Smectite with & 0.28 & 1.23 & 2.75 & 0.63 & 3.38 & 0.81 & 0.67 & 2.39 & 1.78 & 6.35 & 0.62 & 2.21 & 8.66 & 4.39 & 12.07 & 57.14 & 271.43 & 589.29 & 464.29 & 167.87 & 35.71 & 6 \\
\hline 2 & & & 0.90 & 3. & & & & & $\begin{array}{l}0.10 \\
0.05\end{array}$ & & & 5.69 & & $\begin{array}{l}2.682 \\
2.49\end{array}$ & & & $\begin{array}{r}7.50 \\
8.03\end{array}$ & 127,78 & & $\begin{array}{l}200.00 \\
32,67\end{array}-10$ & $\begin{array}{l}105.56 \\
110.30\end{array}$ & 22.22 & 12.22 & 4 \\
\hline 5 & $32-1,105-107$ & Smectit & 0.75 & 3.06 & 3.45 & 5.99 & 9.44 & 0.36 & 0.17 & 0.23 & 5.16 & 6.88 & 0.10 & 0.13 & 9.58 & 4,08 & 12.59 & 132.00 & 66.67 & 313.33 & 200.00 & 61.33 & 26.67 & 6 \\
\hline 6 & $32-2,69-71$ & $\begin{array}{l}\text { Volcaniclastic sity sandstone } \\
\text { aith }\end{array}$ & 0.80 & 2.90 & 1.27 & 7.72 & 8.99 & 0.14 & 0.16 & 0.20 & 5.50 & 6.87 & - & - & 10.16 & 3.62 & 11.23 & 125.00 & 70.00 & 312.50 & 625.00 & 53.75 & 17.50 & 5 \\
\hline 7 & $41-7,144-146$ & 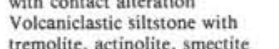 & 0.52 & 2.92 & 2.50 & 4.79 & 7.29 & 0.34 & 0.17 & 0.33 & 5.75 & 11.05 & 0.31 & 0.60 & 8.21 & 5.61 & 14.02 & 307.69 & 121.15 & 307.69 & 317.31 & 48.08 & 26.92 & 5 \\
\hline$a^{2}+2$ & & & & & & & & & & & & & 0.25 & & & & & & 90.16 & & & 49.18 & 1 & 3 \\
\hline 10 & & & & & & & & & & & & & & & $\begin{array}{l}8.42 \\
10.71^{\mathrm{c}}\end{array}$ & & & $\begin{array}{l}151.52 \\
294.12\end{array}$ & 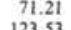 & & & & & \\
\hline $\begin{array}{l}11 \\
12\end{array}$ & & & 0 & 3. & - & 4.0 & & -0.0 & 0.14 & -2 & & 8. & & & & & $\begin{array}{l}12.82 \\
15.05\end{array}$ & 294,12 & 123.53 & 509.80 & 215.69 & 68.62 & 26.79 & - \\
\hline 13 & Unit : & & & & - & - & & - & - & - & & & & & & & & - & $\bar{z}+x+x-1$ & $\overline{-}$ & $\overline{-}$ & $\overline{-}$ & $=$ & $\overline{-}$ \\
\hline 14 & & & & & - & - & & - & - & - & & & & & & & & - & - & - & - & - & - & - \\
\hline 15 & & & & 3. & - & - & & - & - & - & & 7. & & & & & & - & - & - & - & - & - & - \\
\hline 16 & & E & & 3. & $\overline{7}$ & - & 4. & at & $\overline{-1}$ & 0 & 4. & 7. & 0.012 & & . & & & - & - & - & - & - & - & - \\
\hline 17 & $\begin{array}{l}\text { Mid-Atlantic Ridge } \\
\text { (average) }^{\mathrm{a}}\end{array}$ & Tholeitic basalt & 0.83 & 4.19 & 0.77 & 5.59 & 6.36 & 0.12 & 0.12 & 0.14 & 5.14 & 6.14 & 0.06 & 0.0 & & 5.05 & 7.66 & 337.35 & 120.48 & 348.19 & 84.34 & 59.04 & 21.69 & 1 \\
\hline 18 & Galapagos Islands Rift & Tholeitic basalt ${ }^{\mathrm{b}}$ & 1.59 & 3.85 & 1.23 & 6.83 & 8.06 & 0.15 & 0.14 & 0.09 & 4.00 & 2.52 & 0.15 & 0.094 & 0.18 & 2.42 & 5.07 & - & - & - & - & - & - & - \\
\hline
\end{tabular}


Table 4. Results of factor analyses (R-mode) of chemical components of the major types of Cretaceous volcaniclastic deposits, DSDP Site 462.

\begin{tabular}{|c|c|c|c|c|c|c|c|}
\hline \multirow[b]{3}{*}{$\begin{array}{l}\text { Sample } \\
\text { No. }\end{array}$} & \multirow[b]{3}{*}{ Components } & \multicolumn{6}{|c|}{ Factor Loadings } \\
\hline & & \multicolumn{2}{|c|}{$\mathrm{A}^{*}$} & \multicolumn{2}{|c|}{$\mathrm{B}^{*}$} & \multicolumn{2}{|c|}{$\mathrm{C}^{*}$} \\
\hline & & $\begin{array}{c}\text { Factor } \\
\text { Loadings }\end{array}$ & $\begin{array}{l}\text { Rotated } \\
\text { Factor } \\
\text { Loadings }\end{array}$ & $\begin{array}{c}\text { Factor } \\
\text { Loadings }\end{array}$ & $\begin{array}{l}\text { Rotated } \\
\text { Factor } \\
\text { Loadings }\end{array}$ & $\begin{array}{c}\begin{array}{c}\text { Factor } \\
\text { Loadings }\end{array}\end{array}$ & $\begin{array}{l}\text { Rotated } \\
\text { Factor } \\
\text { Loadings }\end{array}$ \\
\hline 1 & $\mathrm{SiO}_{2}$ & 0.97 & 0.88 & -0.17 & -0.45 & & \\
\hline 2 & $\mathrm{TiO}_{2}$ & -0.85 & -0.92 & -0.36 & -0.09 & & \\
\hline 3 & $\mathrm{Al}_{2} \mathrm{O}_{3}$ & -0.99 & -0.94 & 0.002 & 0.31 & & \\
\hline 4 & $\mathrm{Fe}_{2} \mathrm{O}_{3}$ & & & & & 0.86 & 0.82 \\
\hline 5 & $\mathrm{FeO}$ & -0.75 & -0.71 & & & -0.45 & -0.50 \\
\hline 6 & $\mathrm{MnO}$ & 0.79 & 0.88 & 0.47 & 0.14 & & \\
\hline 7 & $\mathrm{CaO}$ & -0.46 & -0.23 & 0.73 & 0.81 & & \\
\hline 8 & $\mathrm{MgO}$ & -0.96 & -0.94 & & & & \\
\hline 9 & $\mathrm{Na}_{2} \mathrm{O}$ & -0.73 & -0.55 & 0.55 & 0.69 & & \\
\hline 10 & $\mathrm{~K}_{2} \mathrm{O}$ & & & -0.78 & -0.90 & -0.51 & -0.16 \\
\hline 11 & $\mathrm{H}_{2} \mathrm{O}^{+}$ & & & 0.85 & 0.78 & -0.05 & -0.39 \\
\hline 12 & $\mathrm{H}_{2} \mathrm{O}^{-}$ & -0.21 & -0.36 & -0.64 & -0.38 & 0.33 & 0.54 \\
\hline 13 & $\mathrm{Cr}$ & -0.89 & -0.86 & & & & \\
\hline 14 & $\mathrm{Ni}$ & 0.60 & 0.74 & 0.64 & 0.34 & -0.14 & -0.34 \\
\hline 15 & v & -0.42 & -0.32 & 0.21 & 0.47 & 0.42 & 0.28 \\
\hline 16 & $\mathrm{Cu}$ & & & 0.55 & 0.27 & -0.56 & -0.73 \\
\hline 17 & Co & 0.43 & 0.61 & 0.70 & 0.55 & & \\
\hline 18 & $\mathrm{~Pb}$ & 0.97 & 0.95 & & & & \\
\hline 19 & Ga & -0.60 & -0.42 & 0.52 & 0.70 & & \\
\hline \multicolumn{2}{|c|}{ Dispersion $(\%)$} & 44.3942 & 44.3942 & 23.7345 & 68.1287 & 10.1934 & 78.3221 \\
\hline
\end{tabular}

-A, B, C are major types of Cretaceous volcaniclastics which are discussed in the text.

Table 5. Stratigraphic distribution of factor scores for chemical components of the major types of the Cretaceous volcaniclastic deposits, DSDP Site 462.

\begin{tabular}{|c|c|c|c|c|c|c|c|c|}
\hline \multirow[b]{3}{*}{$\begin{array}{l}\text { Sample } \\
\text { No. }\end{array}$} & \multirow[b]{3}{*}{$\begin{array}{c}\text { Sample } \\
\text { Designation }\end{array}$} & \multirow[b]{3}{*}{ Age } & \multicolumn{6}{|c|}{ Factor Scores } \\
\hline & & & \multicolumn{2}{|c|}{$\mathrm{A}^{*}$} & \multicolumn{2}{|c|}{$\mathrm{B}^{*}$} & \multicolumn{2}{|c|}{$\mathrm{C}^{\bullet}$} \\
\hline & & & $\begin{array}{l}\text { Factor } \\
\text { Scores }\end{array}$ & $\begin{array}{c}\text { After } \\
\text { Rotation }\end{array}$ & $\begin{array}{l}\text { Factor } \\
\text { Scores }\end{array}$ & $\begin{array}{c}\text { After } \\
\text { Rotation }\end{array}$ & $\begin{array}{l}\text { Factor } \\
\text { Scores }\end{array}$ & $\begin{array}{c}\text { After } \\
\text { Rotation }\end{array}$ \\
\hline 1 & $14-1,75-78 \mathrm{~cm}$ & Cenom.-U. Apt.? & 3.13 & 2.99 & 0.01 & -0.91 & -0.11 & 0.06 \\
\hline 2 & $22-2,70-72$ & U. Apt.? & -0.22 & -0.77 & -1.89 & -1.83 & -0.60 & 0.18 \\
\hline 3 & $22-2,88-90$ & U. Apt.? & -0.41 & -0.76 & -1.46 & -0.93 & 0.60 & 1.10 \\
\hline 4 & $23-1,4-6$ & U. Apt.? & -0.53 & -0.81 & -1.01 & -0.87 & -0.33 & 0.07 \\
\hline 5 & $32-1,105-107$ & U. Apt.? & -0.50 & -0.11 & 1.08 & 1.47 & 1.00 & 0.47 \\
\hline 6 & $32-2,69-71$ & U. Apt.? & -0.49 & -0.31 & 1.06 & 0.29 & -2.00 & -2.27 \\
\hline 7 & $41-7,144-146$ & U. Apt.-Barremian & -0.13 & 0.02 & 0.73 & 0.31 & -0.94 & -1.16 \\
\hline 8 & $42-1,56-58$ & Barremian? & -0.07 & 0.04 & -0.01 & 0.69 & 1.75 & 1.61 \\
\hline 9 & $43-2,138-140$ & Barremian & -0.25 & -0.17 & 0.31 & 0.23 & -0.29 & -0.40 \\
\hline 10 & $80-1,18-21$ & Barremian & -0.24 & -0.23 & 0.01 & 0.02 & -0.14 & -0.15 \\
\hline 11 & $80-2,86-88$ & Barremian & -0.29 & 0.12 & 1.17 & 1.52 & 1.06 & 0.50 \\
\hline
\end{tabular}

-A, B, C are major types of Cretaceous volcaniclastics which are discussed in the text.

sea water. Illitization of volcaniclastic sediments in the lower part of the sequence is absent (below Sample 32-1, $105-107 \mathrm{~cm})$.

\section{Association IIIA (Tables 4 and 5): Ferric Hydroxide: $\mathrm{Fe}_{2} \mathrm{O}_{3}(0.82), \mathrm{H}_{2} \mathrm{O}^{-}(0.54), \mathrm{V}(0.28)$}

This group of components occurs predominantly among relatively oxidized volcaniclastic sediments. The absence of a relatively wide set of heavy metals permits regarding the ferric hydroxide of this association as detrital products formed because of a change of the initial basaltic material.

\section{Association IIIB (Tables 3 and 4): Silicate Phases of Actinolite, Tremolite, Smectite Types: FeO $(-0.50)$, $\mathrm{H}_{2} \mathrm{O}^{+}(0.39), \mathrm{Ni}(-0.34), \mathrm{Cu}(-0.73)$}

This association is most widely distributed in deposits subjected to contact-metasomatic and hydrothermal al- teration, and containing, besides volcaniclastic components, smectite, zeolite, actinolite, and tremolite. Composition of this association can correspond to chemical composition of the minerals.

Geochemical features of tholeiitic volcaniclasticmaterial transformation are shown in Tables 1 and 2, and Figures 1 and 2.

Our study permits identification of a general trend of authigenic transformation of the initial tholeiitic basaltic material in the Nauru Basin in the Cenomanian-Barremian, in the succession from tholeiitic basalts to their volcaniclastites (sandstones, siltstones, silty clays, smectitic clays). The process was accompanied by distinct zeolitization. The products of contact-metasomatic and hydrothermal alteration occupying marginal zones of doleritic sills are of particular interest. Nowadays it is established that in these processes $\mathrm{Ti}$ is a component with relatively little migration ability. Correlation of the 
metal distribution in the deposits (Tables 2, 3; Figs. 9, 10) to intensity of authigenic processes suggests a number of conclusions:

1) $\mathrm{Al}$, like $\mathrm{Ti}$, is distinguished by relatively low mobility; it has an ability to accumulate in residual products (see $\mathrm{Al} / \mathrm{Ti}$, Fig. 9).

2) Fe under conditions of hydrothermal and lowtemperature thermal interaction of volcaniclastic deposits with sea water is leached to some extent and accumulated in sediments predominantly in the form of hydroxides. However, a considerable part of the ferric hydroxides are present in the form of residual products (see $\mathrm{Fe} / \mathrm{Ti}, \mathrm{Fe} / \mathrm{Fe}_{\text {tot }}$, Fig. 9);

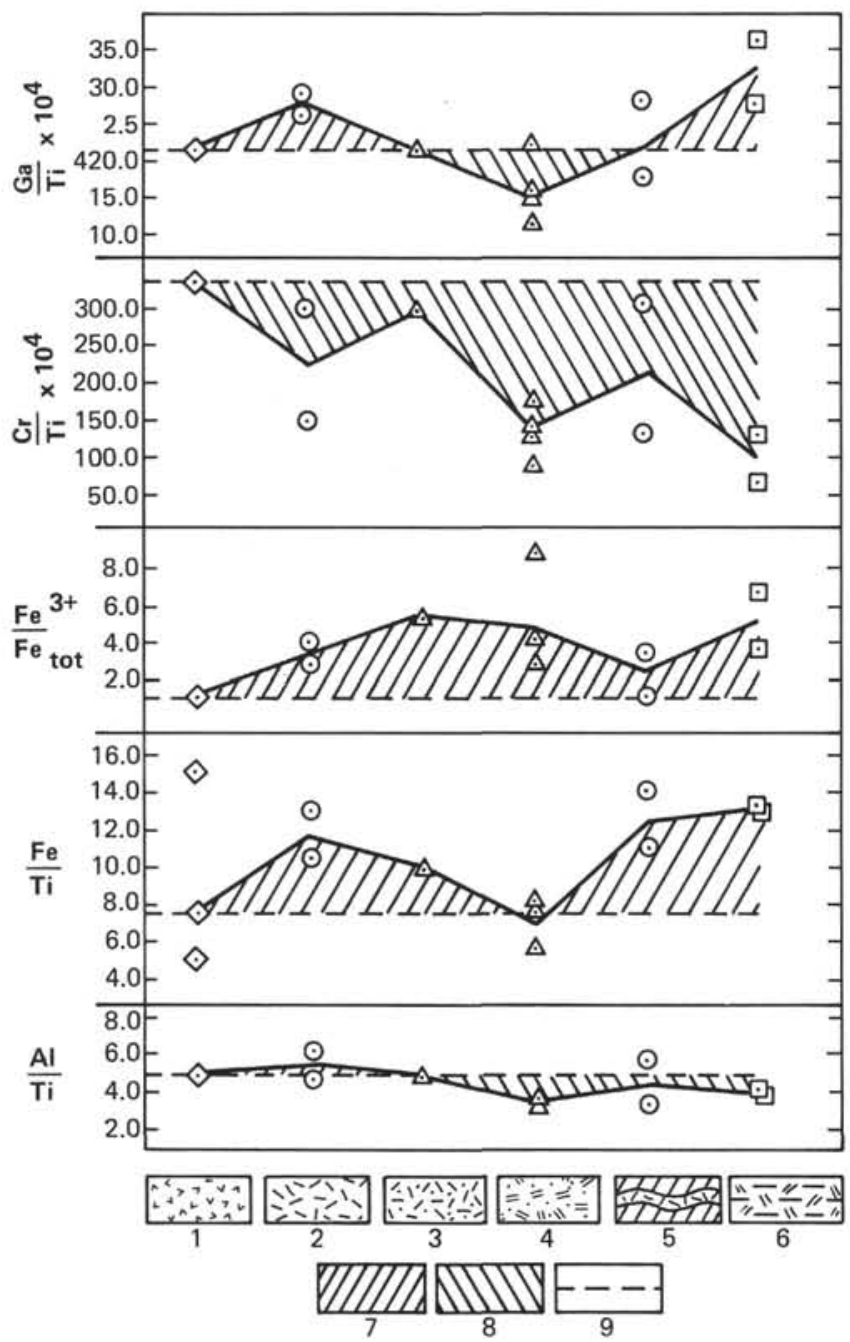

Figure 9. $\mathrm{Al} / \mathrm{Ti}, \mathrm{Fe} / \mathrm{Ti}, \mathrm{Fe}^{3+} / \mathrm{Fe}_{\mathrm{tot}}, \mathrm{Cr} / \mathrm{Ti} \times 10^{4}, \mathrm{Ca} / \mathrm{Ti} \times 10^{4}$ in igneous and main types of volcaniclastic sedimentary rocks (see Table 3). 1, tholeiitic basalt; 2 , volcaniclastic silty sandstone with smectite (Samples 80-1, 18-21 cm; 80-2, 86-88 cm; 3, volcaniclastic silty sandstone (Sample 43-2, 138-140 cm); 4, volcaniclastic siltstone with smectite (Samples 22-2, 70-72 cm; 22-2, 88-90 cm; 23-1, 4-6 cm); 5 , volcaniclastic silty sandstone with contact-metasomatic alteration (Samples 32-2, 69-71 cm; 41-7, 144-146 cm); 6, smectitic clay formed after hyalopelite (Samples 14-1, 75-78 cm; 32-1, 105-107 cm); 7, relative enrichment of component; 8 , relative leaching of component; 9 , content of component in tholeiitic basalt.

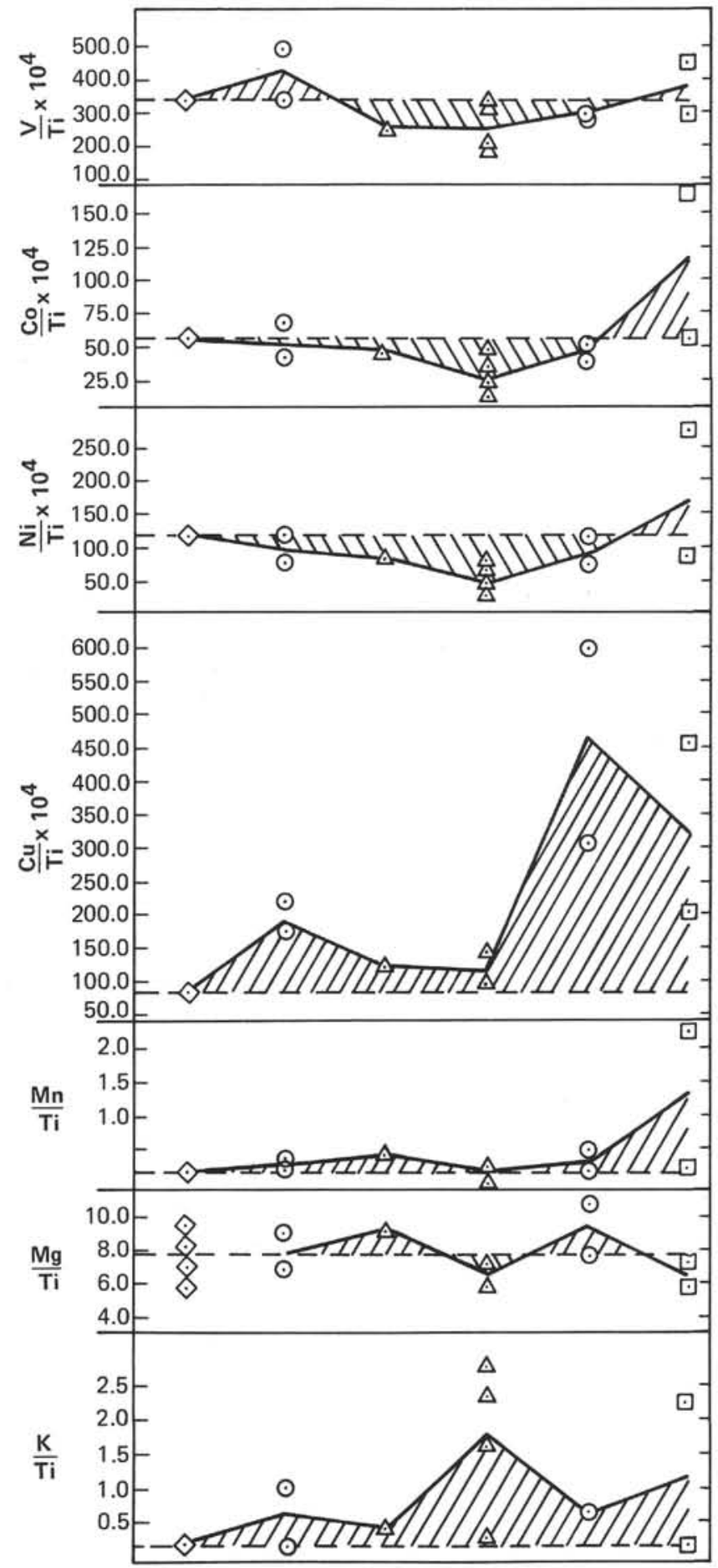

Figure 10. $\mathrm{K} / \mathrm{Ti}, \mathrm{Mg} / \mathrm{Ti}, \mathrm{Mn} / \mathrm{Ti}, \mathrm{Cu} / \mathrm{Ti} \times 10^{4}, \mathrm{Ni} / \mathrm{Ti} \times 10^{4}, \mathrm{Co} / \mathrm{Ti}$ $\times 10^{4}, \mathrm{~V} / \mathrm{Ti} \times 10^{4}$ in main types of volcaniclastic sedimentary rocks (symbols as in Fig. 9; see Table 3).

3) $\mathrm{Cr}$ has a relatively low hydrochemical mobility under these conditions and is accumulated in residual products (see $\mathrm{Cr} / \mathrm{Ti} \times 10^{4}$, Fig. 9).

4) $\mathrm{Ga}$, despite its chemical similarity with $\mathrm{Al}$, has a slightly higher migration ability and is accumulated in the resulting products of alterations, smectitic clays (see $\mathrm{Ga} / \mathrm{Ti} \times 10^{4}$, Fig. 9). 
5) $\mathrm{K}$ is a typical product of authigenic transformations of basaltic volcaniclastic deposits. Content of $\mathrm{K}$ taken from sea water distinctly increases with increase in content of clay components (see K/Ti, Fig. 10).

6) Proportions of $\mathrm{Mn}$ and $\mathrm{Cu}$ considerably increase in the rock sequence concerned from tholeiitic basalts to smectites. Delivery of $\mathrm{Mn}$ and $\mathrm{Cu}$ into the sea water results mainly from hydrothermal interaction. Because of this, the increased content of $\mathrm{Cu}$ in the sediments subjected to contact-metasomatic and hydrothermal alterations is of particular interest (see $\mathrm{Mn} / \mathrm{Ti}, \mathrm{Cu} / \mathrm{Ti} \times$ $10^{4}$, Fig. 10).

The geochemical behavior of $\mathrm{Ni}, \mathrm{Co}$, and $\mathrm{V}$ is distinguished by an accumulation of these elements in smectitic clayey sediments $\left(\right.$ see $\mathrm{Ni} / \mathrm{Ti} \times 10^{4}, \mathrm{Co} / \mathrm{Ti} \times 10^{4}$, $\mathrm{V} / \mathrm{Ti} \times 10^{4}$, Fig. 10).

\section{CEMENT COMPOSITION AND SECONDARY CHANGES OF ROCKS}

An aggregate of clay material and zeolites performs the function of cement in these rocks.

Clay material is of olive-green color. By composition and structure it is identical to clay material developed after volcanic glass particles, three varieties being known.

Clay material of the first variety forms aggregates of irregular shape (Plate 4, Fig. 2). It is either homogeneous or has clumpy, irregular textures in transmitted light; under crossed nicols, its shows a coarse-aggregate or cloudy extinction, being frequently almost isotropic. In its habit it is identical to coarse-aggregate clay material developed after basaltic volcanic glass. It appears to be a product of palagonite substitution by clay minerals. This type of cement is peculiar to volcaniclastic sandstones of Samples 42-1, 54-56 cm; 42-1, $56-58 \mathrm{~cm} ; 42-2$, $95-97 \mathrm{~cm} ; 43-1,140-142 \mathrm{~cm}$; $80-1$, $10-13 \mathrm{~cm} ; 80-1,18-21 \mathrm{~cm} ; 80-2,86-88 \mathrm{~cm}$; and $80-2$, $88-90 \mathrm{~cm}$. Of considerable importance in these clastogenic components are particles of volcanic glass replaced by clay material of homogenous structure.

The second variety of material is represented by a finely dispersed mass of equant or elongated particles not over $2 \mu \mathrm{m}$ (Plate 4, Fig. 1). Such particles are quite disorderly in orientation, but in some sandstones they form incrustate rims on the peripheries of pores in which the elongated clay particles are oriented toward the center. Clay material of such structure has been recognized in volcaniclastic siltstones and fine-grained sandstones of Samples 22-2, 70-72 cm; 22-2, 88-90 cm; 23-1, 0-2 cm; and 23-1, 4-6 cm. The similar structure of clay material is clearly correlated to wide development of particles replaced by finely dispersed clay material.

The third variety is composed of relatively large particles (up to $10-20 \mu \mathrm{m}$ ), forming single patches, fan-like aggregates, or incrustate rims on the pore periphery (Plate 4, Fig. 5). Such rims are frequently separated from clastic grains by a film of red-brown $\mathrm{Fe}$-hydroxides up to $2 \mu \mathrm{m}$ wide. Clay particles are characterized by well pronounced pleochroism, from green color to greenish-yellow. Refraction indices are $\mathrm{Ng}_{1}=1.570$, $\mathrm{Np}_{1}=1.540, \mathrm{Ng}-\mathrm{Np}=0.030$.
The third variety of clay material in cement is characteristic of volcaniclastic claystones, siltstones, and sandstones in Samples 32-1, 105-107 cm; 32-1, 148-150 cm; $32-2,69-71 \mathrm{~cm} ; 32-2,71-73 \mathrm{~cm} ; 40-1,140-142 \mathrm{~cm} ; 40-1$, $148-150 \mathrm{~cm} ; 41-2,81-83 \mathrm{~cm} ; 41-7,109-111 \mathrm{~cm}$; and $41-7,144-146 \mathrm{~cm}$. Fragments of volcanic glass replaced by clay material in these rocks are characterized by large dimensions of particles of clay material and their distinct differentiation.

Cement in sandstones of Samples 43-1, 86-89 cm and $43-2,138-140 \mathrm{~cm}$ abounds in fine-grained opaque material representing finely dispersed altered hyalobasalt. The role of such material in the composition of clastogenic components of these rocks is very great.

$\mathrm{X}$-ray structure analysis of the $<0.001-\mathrm{mm}$ fraction showed that highly ferruginous smectite-nontronite is seldom predominant in its composition. This mineral is peculiar not only to the mass of cement, but also to glass particles replaced by clay. In diffractograms of air-dried samples (Fig. 5), this mineral yields an intense reflection, with $d(001)$ varying from 12 to $15 \AA$. The phase with $d(001)=12 \AA$ contains one molecule of water in interlayer spaces; among the cations of the saturated complex, $\mathrm{Na}^{+}$(and possibly $\mathrm{K}^{+}$) prevails. The phase with $d(001)=15 \AA$ contains two molecules of water, $\mathrm{Ca}^{2+}$ being predominant in its saturated complex. In siltstone of Sample 23-1, 0-2 cm, both phases are present simultaneously.

In diffractograms of samples saturated with glycerine, nontronite relates to a series of basal deposits, with $d(001)$ equal to 17.8 to $18.2,9.01$ to $0.06,4.48$ to 4.52 , and $3.01 \AA$; and in diffractograms of samples heated at $550^{\circ} \mathrm{C}, d=9.8$.

The high content of $\mathrm{Fe}$ in the mineral composition is indicated by the low intensity of reflections of the third and fourth orders at high intensity of reflections of the second and fifth orders. The irrational character of basal reflections in samples saturated with glycerine bespeaks the presence of insignificant amounts of illite in the nontronite composition.

Illite as an independent phase is present in the clay fraction of claystone of Sample 14-1, 66-69 cm (reflection with $d=10 \AA$ in a sample saturated with glycerine). This sample differs significantly from sedimentary rocks of the underlying horizons in the rather high illite content of the clay fraction.

The clay fraction of almost all studied samples contains a small admixture of zeolite (reflections with $d=$ $5.6 \AA$ in an air-dried, glycerine-saturated, and heated state).

Zeolite of the cement forms either small $(2-3 \mu \mathrm{m})$, platy crystals of irregular shape within the mass of clay material, or patches filling the greater part of pores, frequently replacing many clastogenic components, including unaltered and palagonitized glass, plagioclases, pyroxene, and fragments composed of clay material of homogenous structure. Such patches usually consist of irregular, equant plates; in some cases, however, zeolite forms radial aggregates (Plate 4, Figs. 2-5).

The refraction indices of zeolite vary from 1.486 to 1.501. The presence of two mineral species is probable. 
One of them is practically isotropic, the refraction index varying from 1.486 to 1.492 ; the second variety is characterized by birefringence (gray interference color) and refraction indices varying from 1.493 to 1.501 . Zeolite of the first sort appears to be analcite, the second wairakite.

X-ray study of the light part of the 0.1 to $0.01-\mathrm{mm}$ fraction showed the presence of analcite only. In diffractograms (Fig. 6), this mineral is reliably diagnosed through a series of reflections $(d=5.60,4.86,3.66$, $3.43,2.92,2.80,2.69,2.50,2.42 \AA)$. In the analyzed fraction, the smectite reflection with $d(001)=14.7$ to $15.3 \AA$ is present too.

In siltstones and sandstones from Cores 32-1, 32-2, 40-1, 41-2, and 41-7-along with analcite and wairakite developing after glass fragments and other components- one more zeolite is present. It fills porous spaces and forms slightly elongated plates oriented toward the center of the pores (Plate 4, Figures 4, 5). Needle-like patches of green clay (nontronite) are present here as well.

We failed to isolate this mineral from the rocks. Its refraction indices are 1.535 to 1.540 (refraction index of balsam), and birefringence is low, corresponding to the gray and dark-gray interference color. This mineral appears to correspond to calcic zeolite (thomsonite possibly).

In samples with zeolite of the third variety, needlelike or short-prismatic crystals of a colorless or palegreen mineral are present. They not only are formed in cement, but also together with finely dispersed clay material replace many clastogenic components (volcanic glass of different varieties, plagioclases; Plate 4, Figs. $5,6)$.

The refraction indices of such crystals are: $\mathrm{Ng}_{1}=$ $1.700 \mp 2 ; \mathrm{Np}_{1}=1.686 \mp 2 ; \mathrm{Ng}-\mathrm{Np}=0.014$. Extinction is oblique $\left(\mathrm{C}: \mathrm{Ng}=12-15^{\circ}\right)$, the cleavage being parallel to elongation. By their optical features, these crystals correspond to ferruginous monoclinic amphiboles (tremolite and actinolite).

This has been confirmed by X-ray analysis of the 0.1 to $0.01-\mathrm{mm}$ fraction from fine-grained sandstone of Sample 41-7, 109-11 cm, containing the highest concentrations of these minerals. In the diffractogram (Fig. 7), a great number of reflections testify to the polymineralic character of the studied material. The presence of monoclinic pyroxenes (actinolite and tremolite) is evidenced by a series of reflections with $d=8.50,4.99,3.32,3.12$, $2.72,2.52$, and $1.505 \AA$.

The peculiarities of distribution of various types of clay material and authigenic zeolites and amphiboles in sedimentary rocks through the lower part of Site 462 are summarized in Figure 8.

The wide distribution of authigenic zeolites and monoclinic amphiboles within sedimentary rocks of the lower part of Site 462 testify to intense manifestations of post-sedimentary transformations in these rocks.

Authigenic zeolites in sediments and sedimentary rocks are formed in the course of diagenetic (true diagenetic and catagenetic, as Soviet lithologists distinguish them) processes. Phillipsite and clinoptilolite are the only diagenetic zeolites established in sea and oceanic sediments. Other minerals of the zeolite group do not appear to form in diagenesis.

Formation of authigenic analcite, wairakite, and thompsonite during hydrothermal changes of terrigenous and volcanogenic sedimentary rocks occurring at present on land has been described by many researchers. Their data are summarized by Deer et al. (1963); Senderov and Khitarov (1970) showed that the most frequent hydrothermal processes resulting in formation of the three above-mentioned zeolites appear in areas of manifestation of magmatic activity of basic composition.

The study of geological processes and experimental studies show that analcime forms and is stable in the temperature interval from about $100^{\circ}$ to $500^{\circ} \mathrm{C}$ (Deer et al., 1963; Senderov and Khitarov, 1970; Dobretsov et al., 1972).

Formation of wairakite in sedimentary and volcanogenic-sedimentary rocks of New Zealand is proceeding at 200 to $250^{\circ} \mathrm{C}$, whereas thomsonite appears to originate at 240 to $280^{\circ} \mathrm{C}$. Montmorillonite seems to be stable up to 350 to $380^{\circ} \mathrm{C}$ (Dobretsov et al., 1972).

The temperatures of formation and stability of these minerals are certain to be rather tentative, as the processes of zeolite formation and those of clay minerals are affected not only by temperature, but by other factors as well: pressure, chemical properties of solutions, etc.

Authigenic actinolite and tremolite are known as minerals of the early stages of regional metamorphism. They are formed by alteration of some sedimentary rocks - such as dolomites rich in $\mathrm{SiO}_{2}$-but their formation is most characteristic in metamorphism of basic igneous rocks (Deer et al., 1963).

Actinolite is a peculiar mineral of some skarns (carbonate or aluminosilicate rocks subjected to metasomatic replacement in the zone of contact with intrusive bodies; Dobretsov et al., 1972). Actinolite is characterized of medium- and low-temperature skarns of shallow depths, where it is formed with epidote, zoisite, prehnite(?), and vesuvianite. Some experimental work shows that formation of this mineral could take place in a wide temperature interval, from 300 to $650^{\circ} \mathrm{C}$.

In sedimentary rocks in contact with igneous rocks, formation of thomsonite has been observed as well (Deer et al., 1963).

These data show that post-sedimentary transformations established in sedimentary rocks of the lower part of Site 462 were related to contact-metasomatic and hydrothermal influence of enclosing igneous rocks. Contact-metasomatic changes manifested themselves in samples of Cores 32,40 , and 41 , where authigenic amphiboles are present, and where crystallization of clay material is widely developed. Practically all rocks were influenced by hydrothermal processes. These were associated not only with formation of authigenic zeolites, but also perhaps with the replacement of volcanic glass particles by clay material. This explains the irregular, sharply triangular outlines of many fragments which have undergone such replacement, and the clear correlation of composition and structure of clay material 
developing after fragments of volcanic glass and in cement of rocks.

One can assume that the possible temperatures in the contact-metasomatic changes were only a little higher than $300^{\circ} \mathrm{C}$, whereas hydrothermal changes took place at temperatures somewhat lower than $300^{\circ} \mathrm{C}$.

\section{DISCUSSION}

The characteristics of sedimentary rocks from the lower part of Site 462 shows that they are mainly hyaloclastites.

The rightfulness of attributing the rocks under study to hyaloclastites is confirmed by their association with a thick complex of basic igneous rocks formed by underwater eruptions, and by peculiarities of their composition. They consist almost entirely of decomposition products of tholeiitic basalts: slightly altered sideromelanic basaltic glass, the same glass subjected to palagonitization of various intensity and replaced by clay material, and fragments of altered hyalobasalts. They also contain plagioclases and accessory minerals characteristic of basic rocks.

Volcanic glass corresponding to intermediate igneous rocks shows that pyroclastic material participated in the formation of these rocks. Sideromelanic glass is characterized by considerable unstability. Its transformation into palagonite, and then into clay minerals, can proceed immediately after eruption of lavas, during transportation of glass particles, in the course of sediment diagenesis, and in low-temperature hydrothermal processes. At each of these stages, of decisive importance was the interaction of sideromelane with sea water, and interstitial solutions of sediments and rocks similar in composition to sea water.

We have no data that enable us to correlate with confidence the palagonitization developed after sideromelanic glass and formation on nontronite to one or another stage. The sharply triangular shape of many particles subjected to palagonitization and replacement by clay material can be regarded as evidence that transformation of glass was proceeding in situ, i.e., after burial in the sediment. This is also evidenced by the incrustate structure of finely dispersed clay material of cement in some of the samples from the upper part of the section. However, this can be true only for a part of the fragments of palagonitized sideromelanic glass and clay material in cement.

The sedimentary rocks under consideration are relatively deep-water sediments. This is confirmed both by the absence of organic remains (remains of organisms with a carbonate skeleton, above all), and by such peculiarities as poor sorting and vague lamination.

The structural-textural peculiarities of the rocks, the character of mutual transitions of various lithologic types, the poor sorting, and the high content of clay material show that accumulation was a result of turbidity currents. Such sediments, as well as the mechanism of their formation, are thoroughly studied in the works by Kuenen $(1953)$ and Bouma $(1962,1965)$. The sedimentary rocks concerned contain most of the structural-textural varieties of sediments typical to tur- bidites. It is not excluded that some rock types with oblique lamination were formed by currents. The wide distribution of turbidites is quite natural for areas of deepwater oceanic sedimentation with an active tectonic regime and repeated manifestations of volcanic activity.

The coarse-grained sediments (conglomerates and breccias) in some horizons show that some turbidity flows originated on bottom elevations near Site 462. It is natural that the material composing these horizons underwent very limited dislocations. Slide textures in sediments bespeak an uneven surface of the bottom. Some of the textures indicate underdeveloped turbidity flows characterized by negligible dislocations of material along the slope.

Interaction of sediments with sea water, and hydrothermal and contact-metasomatic processes were of great importance during lithification of sediments and their transformation into sedimentary rocks. Formation of actinolite, tremolite, and thompsonite characteristic of volcaniclastic rocks from Cores 32,40 , and 41 was connected with contact-metasomatic processes. Formation of analcite and wairakite, displayed to a greater or lesser extent in all lithologic varieties, took place under the influence of hydrothermal processes. At low-temperature stages of the hydrothermal process, replacement of volcanic glass, or products of its earlier palagonitization, by nontronite could take place.

Geochemical study of these Cretaceous volcaniclastic sediments permits regarding them as products of authigenic transformation of tholeiitic basalt materials during their interaction with sea water. Hydrothermal and, in some cases, contact alterations considerably affected these processes. There is a distinct increase of $\mathrm{K}, \mathrm{Fe}^{3+}$, $\mathrm{Mn}$, and heavy metals $(\mathrm{Cu}, \mathrm{Ni}, \mathrm{Co}, \mathrm{V})$ in this rock sequence from tholeiitic basalts to their volcaniclastites (sandstones, siltstones, silty clays, $\mathrm{Fe}-\mathrm{Mg}$ smectites).

A similar increase in the intensity of reworking of volcanogenic material and authigenic processes is observed in the lower horizons of the sequence (the Barremian), and towards the upper part (the Cenomanian). Distribution of the paragenetic-association components corresponding to particular mineral phases shows that a wide, regional, relatively low-temperature interaction between the tholeiitic material and sea water was most significant in the process of authigenic transformations.

\section{REFERENCES}

Bailey, J. C., and Noe-Nygaard, A., 1976. Chemistry of Miocene plume tholeiites from Northwest Island. Lithos, 9:185-201.

Bouma, A. H., 1962. Sedimentology of Some Flysch Deposits: Amsterdam (Elsevier).

1965. Notes on X-ray interpretation of marine sediments. Mar. Geol., 2:278-309.

Campsie, E. J., Bailey, J. C., and Rasmussen, M., 1973. Chemistry of tholeiites from the Galapagos Islands and adjacent ridges. Nature, 245:122-124.

Davis, J. C., 1973. Statistics and Data Analysis in Geology: New York (Wiley).

Deer, W. A., Howie, R. A., and Zussman, J., 1963. Rock-Forming Minerals (Vol. 4): London (Longmans).

Dobretsov, N. L., Sobolev, V. S., and Khlestov, V. V., 1972. Facies of Regional Metamorphism of Medium Pressures: Moscow (Nedra). 
Geptner, A. R., 1978. Palagonite and the processes of palagonitization. Lithol. Mineral Res., 12:511-616.

Harman, H. H., 1967. Modern Factor Analysis (2nd Ed): Chicago (Univ. Chicago Press).

Hay, R. L., and Ijima, A., 1968. Nature and origin of palagonite tuffs of the Honolulu Group of Oahu, Hawaii. Geol. Soc. Am. Mem., 116.

Hekinian, R., and Thompson, G., 1976. Comparative geochemistry of volcanics from rift valleys, transform faults and seismic ridges. Contr. Mineral. Petrol., 57:145-162.

Kuenen, $\mathrm{Ph} . \mathrm{H} ., 1953$. Significant features of graded bedding. Bull. Am. Assoc. Petrol. Geol., 37:1044-1066.

Melson, W. G., and Thompson, G., 1971. Petrology of a transform fault zone and adjacent ridge segments. Royal Soc. London Phil. Trans., 268:423-441.

Senderov, E. E., and Khitarov, N. I., 1970. Zeolites-Their Synthesis and Conditions of Formation in Nature: Moscow (Nauka).

Seyfreid, W., and Bishoff, J., 1977. Hydrothermal transport of heavy metals by seawater: the role of seawater/basalt ratio. Earth Planet. Sci. Lett., 34:71-77.
Stokes, K. R., 1971. Further investigations into the materials chlorophaeite and palagonite. Mineral. Mag., 38:205-214.

Thompson, G., Shido, F., and Miyashiro, A., 1972. Trace element distribution in fractionated oceanic basalts. Chem. Geol., 9:89-97.

Tröger, W. E., 1952. Tabellen zur Optischen Bestimmung der Gesteinsbilden Minerale: Stuttgart.

Varentsov, I. M., 1971. On the leaching of manganese in the course of interaction of basic volcanic materials with sea water. Soc. Mining Geol. Japan, Spec. Issue, 3:466-473.

1976. Lithologic-mineralogic studies of the sedimentary deposits from Hole 350, DSDP Leg 38. In Talwani, M., Udintsev, G., et al., Init. Repts. DSDP, 38: Washington (U.S. Govt. Printing Office), 111-120.

Zolotarev, B. P., and Choporov, D. Y., 1978. Petrochemistry of basalts D/V Glomar Challenger, Leg 45, Holes 395 and 396. In Melson, W. G., Rabinowitz, P. D., et al., Init. Repts. DSDP, 45: Washington (U.S. Govt. Printing Office), 479-492. 

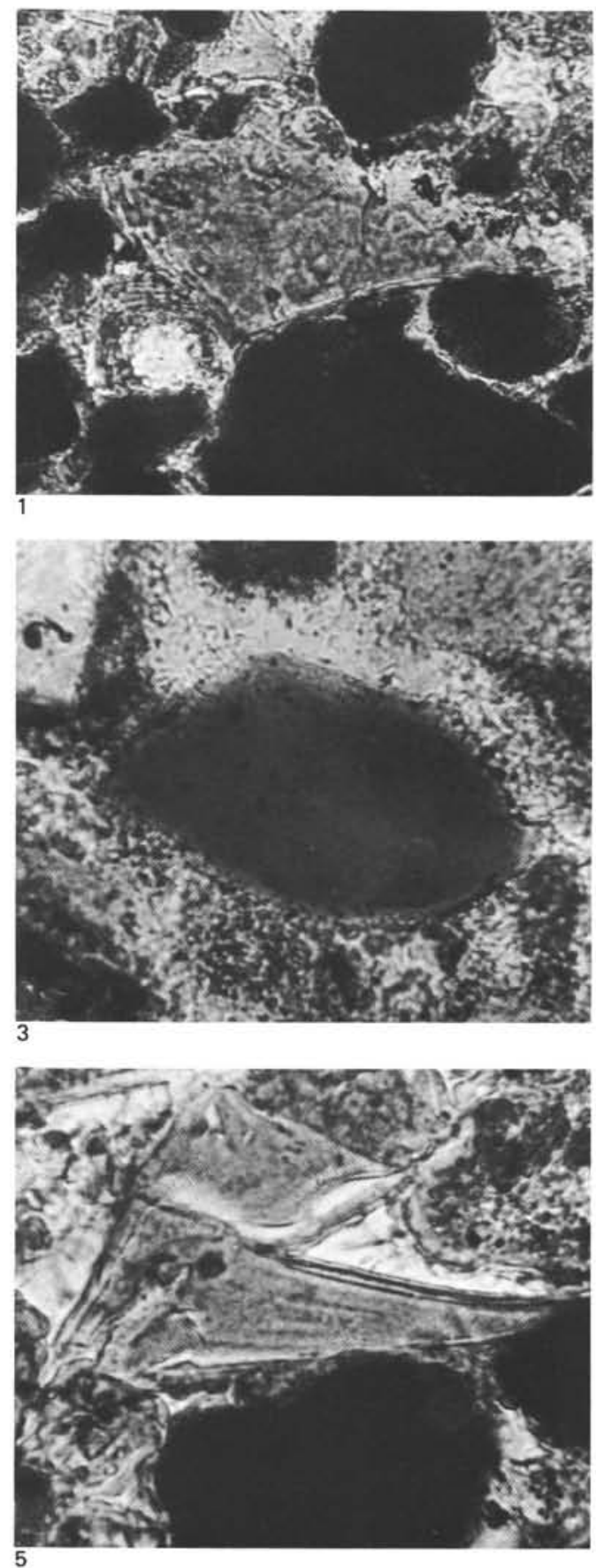

Plate 1. Photomicrographs.

Figure 1. Fragment of slightly altered basaltic glass; parallel nicols; $\times 850$; Sample $80-2,85-90 \mathrm{~cm}$.

Figure 2. Fragment of basaltic glass, slightly altered in the center and appreciably palagonitized along the periphery; parallel nicols; $\times 300$; Sample 42-2, 95-97 cm.

Figure 3. Light-brown fragment of slightly palagonitized basaltic glass; parallel nicols; $\times 250$; Sample $80-2,88-90 \mathrm{~cm}$.
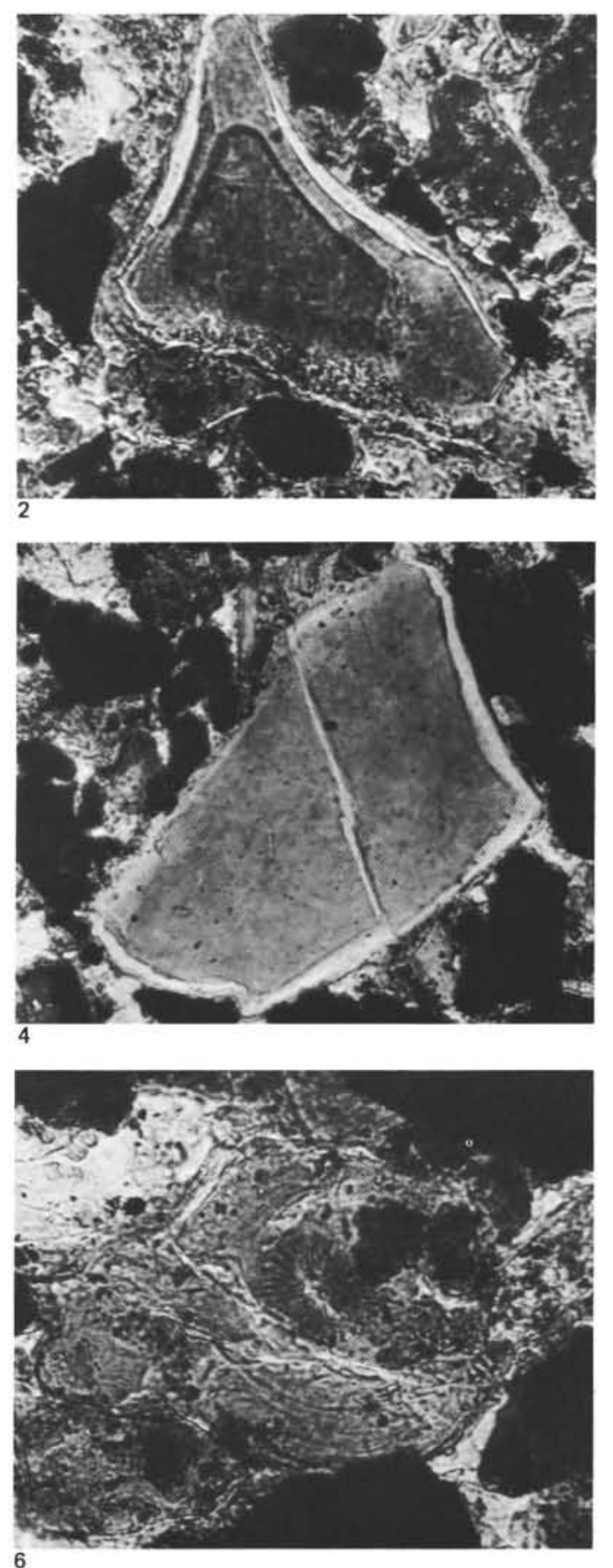

Figure 4. Olive-green fragment of deeply palagonitized basaltic glass; parallel nicols; $\times 850$; Sample $23-1,4-6 \mathrm{~cm}$.

Figure 5 . Wedge-shaped fragment of basaltic glass replaced by homogeneous clay material; parallel nicols; $\times 600$; Sample $80-2,88-90$ $\mathrm{cm}$.

Figure 6. Fragment of basaltic glass replaced by homogeneous clay material; in the center is a vesicle filled with incrustate clay material of an earlier generation; parallel nicols; $\times 600$; Sample $80-2,88-90 \mathrm{~cm}$. 

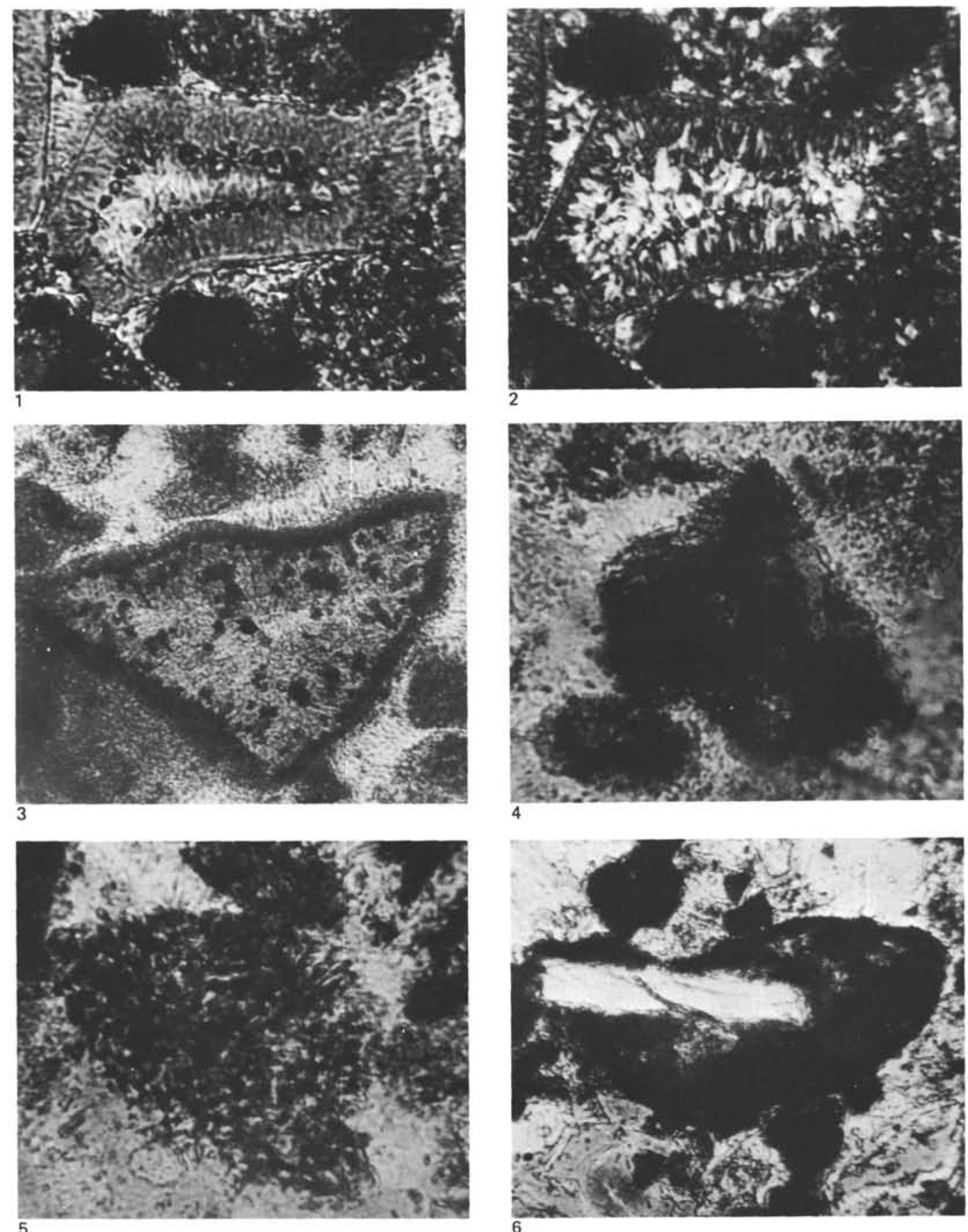

Plate 2. Photomicrographs.

Figures 1, 2. Fragment of basaltic glass replaced by finely-dispersed clay material, with an incrustate rim along the grain margin; 1 : parallel nicols; 2: crossed nicols; $\times 1000$; Sample $23-1,0-2 \mathrm{~cm}$.

Figure 3. Fragments of basaltic glass replaced by clay material of relatively coarse-aggregate structure; a visible rim of $\mathrm{Fe}$ -

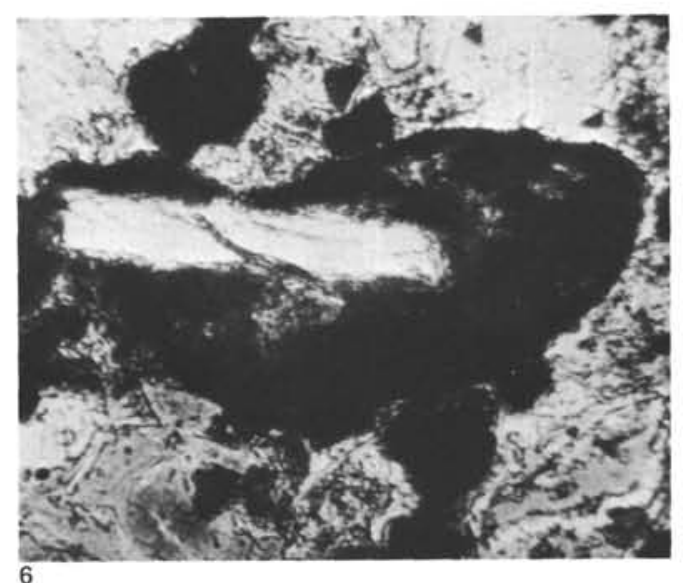

hydroxides coats the fragment; parallel nicols; $\times 600$; Sample $40-1,148-15 \mathrm{~cm}$.

Figure 4. Large and small fragments of altered hyalobasalts; parallel nicols; $\times 850$; Sample 23-1, 0-2 cm.

Figure 5. Fragment of altered hyalobasalt with microlites of plagioclase; parallel nicols; $\times 850$; Sample $23-1,0-2 \mathrm{~cm}$.

Figure 6. Fragment of altered hyalobasalts with a plagioclase lath; parallel nicols; $\times 360$; Sample $40-1,148-150 \mathrm{~cm}$. 

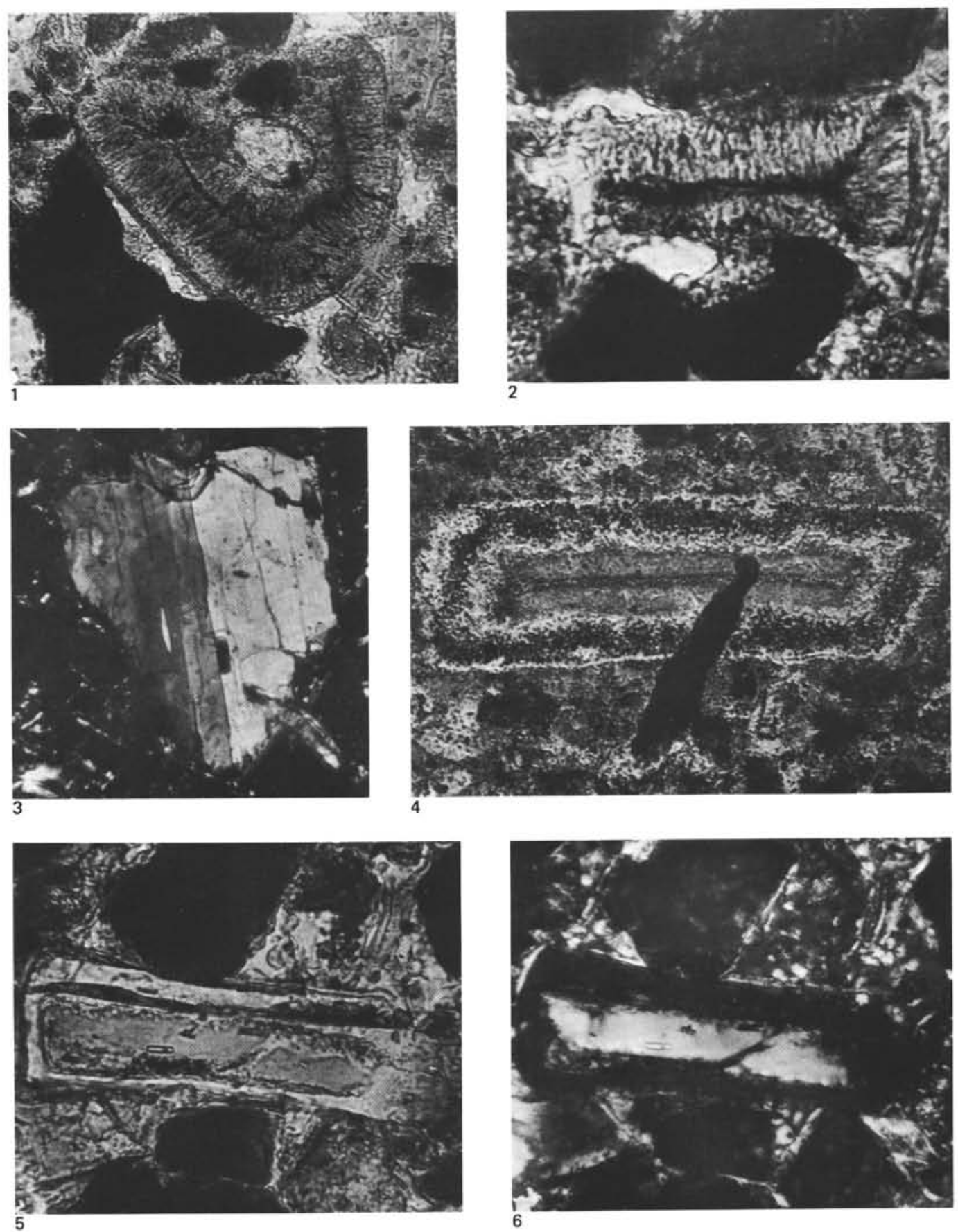

Plate 3. Photomicrographs.

Figure 1. Rounded fragment of semicrystalline basaltic glass of incrustate structure; parallel nicols; $\times 400$; Sample $80-2,88-90 \mathrm{~cm}$.

Figure 2. Rectangular fragment of semicrystalline basaltic glass of incrustate structure; parallel nicols; $\times 600$; Sample $88-2,88-90 \mathrm{~cm}$.

Figure 3. Fragment of plagioclase of perfect preservation; negligible corrosion of the surface with clay material of cement, crossed nicols; $\times 300$; Sample $80-2,88-90 \mathrm{~cm}$.

Figure 4. Fragment of plagioclase replaced by zeolite (thomsonite?), with $\mathrm{Fe}$-hydroxide in the peripheral part and finely dispersed clay material in the center; parallel nicols; $\times 250$; Sample 41-7, 109-111 $\mathrm{cm}$.

Figures 5, 6. Fragment of plagioclase replaced by analcite in the peripheral part and homogeneous clay material in the central part; 5: parallel nicols; 6: crossed nicols. 


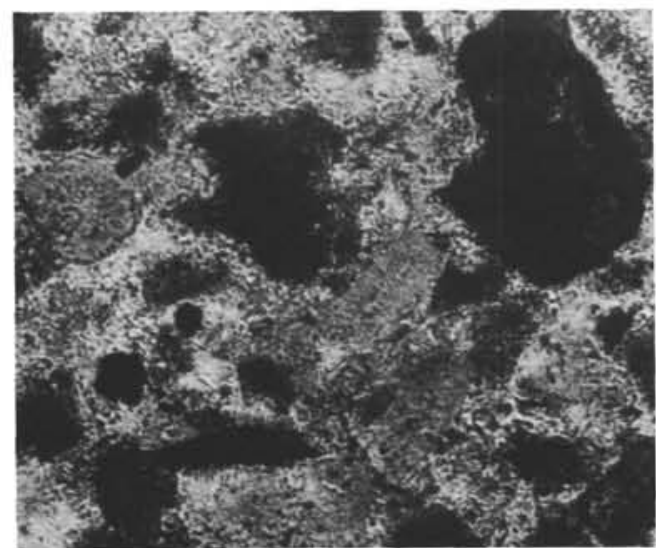
1

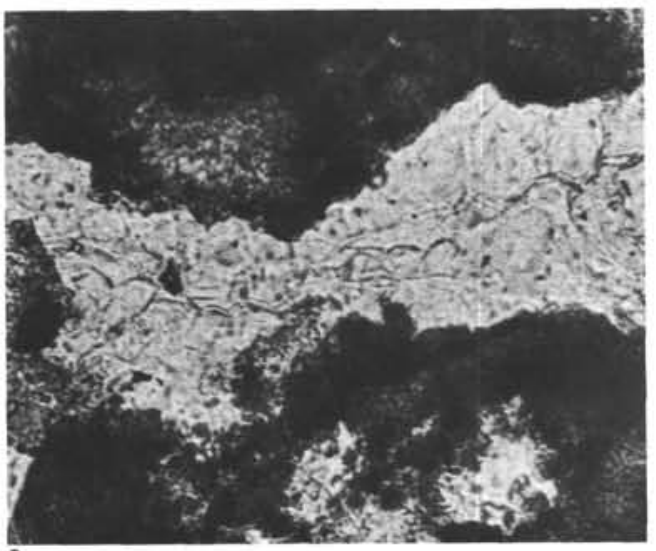

3

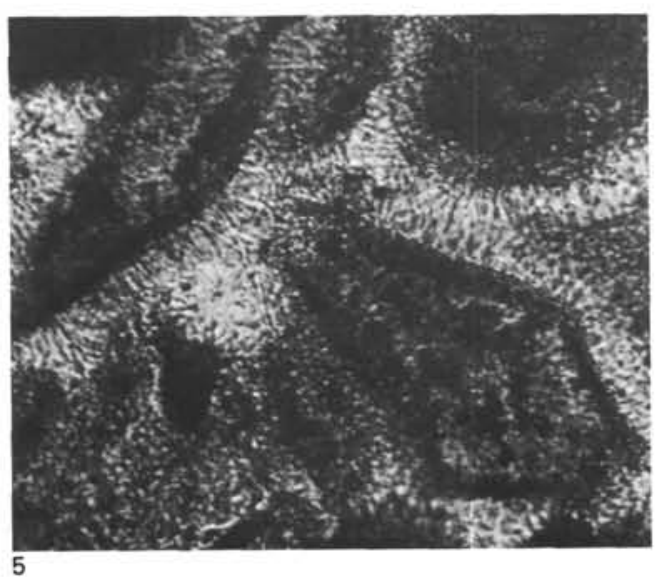

Plate 4. Photomicrographs.

Figure 1. Habit of zeolite (analcite) and homogeneous clay material in cement of volcaniclastic medium-grained sandstone; parallel nicols; $\times 700$; Sample 42-2, 95-97 cm.

Figure 2. Habit of volcaniclastic siltstone with finely dispersed clay material in cement; parallel nicols; $\times 600$; Sample $23-1,0-2 \mathrm{~cm}$.

Figure 3. Analcime in cement of coarse-grained sandstone; parallel nicols; $\times 600$; Sample $80-1,10-13 \mathrm{~cm}$.
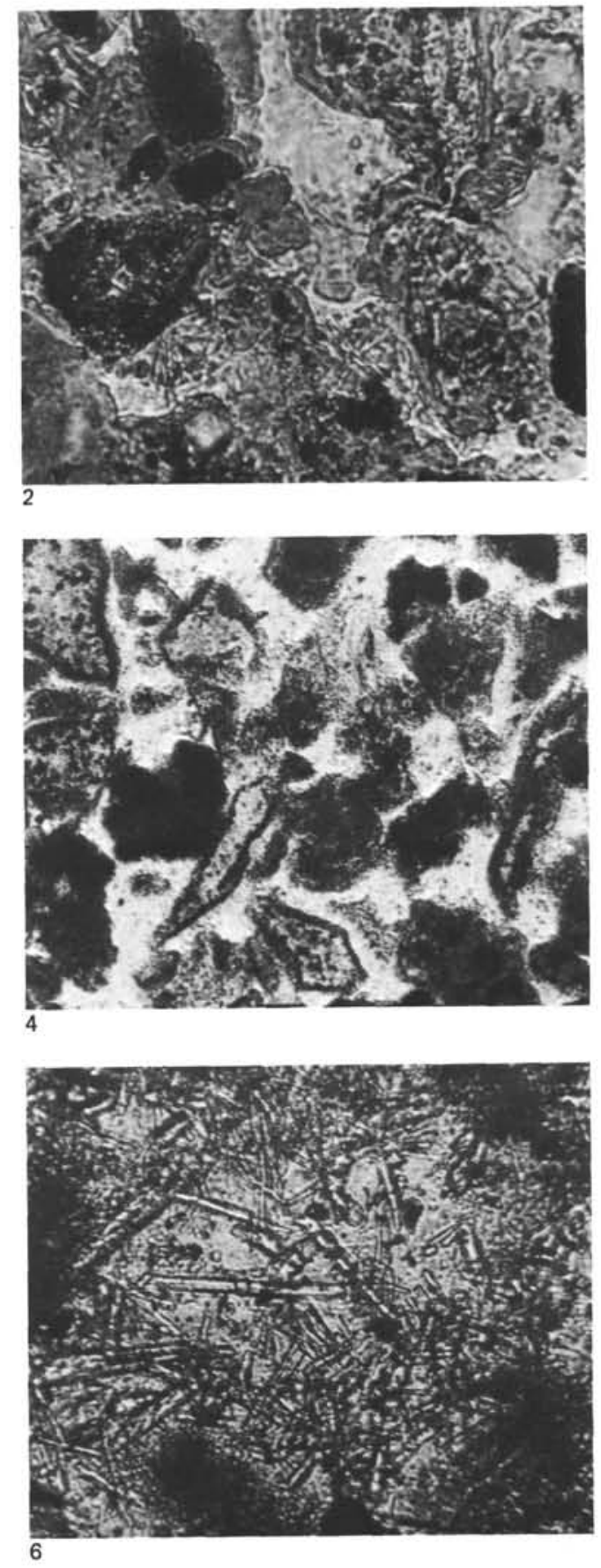

Figure 4. General appearance of fine-grained volcanomictic sandstone with zeolite (thomsonite?) in cement; zeolite replaced all clay material and some fragments of glass; parallel nicols; $\times 200$; Sample $40-1,148-150 \mathrm{~cm}$.

Figure 5. Volcaniclastic sandstone with zeolite (thomsonite?) in cement; visible needle-like crystals of newly formed amphiboles and incrustate clay material along the peripheries of pores, and aggregates of Fe-hydroxides along the boundaries of the fragment; parallel nicols; $\times 600$; Sample 40-1, 148-150 cm.

Figure 6. Newly formed amphiboles in volcaniclastic fine-grained sandstone; parallel nicols; $\times 720$; Sample $41-7,109-111 \mathrm{~cm}$. 